\title{
Changes of Spatial Characteristics: Socio-Cultural Sustainability in Historical Neighborhood in Beijing, China
}

\author{
Huiming Liu (1) and Bin Li * \\ Laboratory for Future City, School of Urban Planning and Design, Shenzhen Graduate School, Peking University, \\ Shenzhen 518055, China; liuhuiming@pkusz.edu.cn \\ * Correspondence: libin@pkusz.edu.cn; Tel.: +86-186-2870-6470
}

Citation: Liu, H.; Li, B. Changes of Spatial Characteristics: Socio-Cultural Sustainability in Historical Neighborhood in Beijing, China. Sustainability 2021, 13, 6212. https://doi.org/10.3390/su13116212

Academic Editor: Manuel Duarte Pinheiro

Received: 23 April 2021

Accepted: 26 May 2021

Published: 31 May 2021

Publisher's Note: MDPI stays neutral with regard to jurisdictional claims in published maps and institutional affiliations.

Copyright: (c) 2021 by the authors. Licensee MDPI, Basel, Switzerland. This article is an open access article distributed under the terms and conditions of the Creative Commons Attribution (CC BY) license (https:/ / creativecommons.org/licenses/by/ $4.0 /)$.

\begin{abstract}
This paper uses a typological approach as a tool to establish an analytical framework from a physical perspective to understand 'place' and to identify key spatial characteristics that could adapt to local needs to deliver socio-cultural sustainability. Six representative housing types with their spaces and uses that were introduced in a historic neighborhood in Beijing, China are selected as case studies. Their morphological characteristics at the building, open space and neighborhood scales are examined, and typological transformations among the cases in terms of the degree of spatial continuity are identified. The paper proposes an analytical framework consisting of fifteen indicators to assess socio-cultural sustainability at the different morphological scales (building, open space and block/neighborhood) of the residents of the six cases. The score of changes from its original design is brought into calculations of continuities of spatial characteristics, which present the transitions and transformations of morphological characteristics in relation to adaptation of local needs and uses. The analysis results show that the spatial characteristics were changed when political-socioeconomic ideologies changed, and local needs and uses were transformed to follow these mutations, and finally, the methods of use in different morphological scales mostly differed from historical norms. Although the continuities of spatial characteristics were significantly changed, they are positively and continually accommodating the transformations and transitions of local needs and uses. On the other hand, the invariant spatial characteristics are important, which last despite transformation of the city development and changing of political-social-economic ideologies, and could be maintained for future development to enhance sociocultural sustainability.
\end{abstract}

Keywords: socio-cultural sustainability; typological approach; urban morphology; neighborhood; spatial characteristics; urban transformation

\section{Introduction}

In the past few decades, the international architecture has been accused of incompatibility with the local cultures [1], and is commonly believed to be responsible for placelessness, particularly in China [2-5]. Many Chinese cities are suffering from a typological crisis and a loss of adaptation to local needs. Especially in Beijing, due to dramatically increased population, traditional courtyard housing types were largely transformed into court-no-yard houses, and turned from one family owned to multi-family occupied [6]. Meanwhile, since the Modernist movement, mass production of standardized houses was free planned into historical neighborhoods to fulfill emerging housing demands. As a result, they devised a built environment, and transformed the spatial network organically to balance the changing needs and transitions of the physical setting $[7,8]$. This leads to two questions which need to be asked:

(1) Is current built environment (both historic and early modern) responsive to sociocultural needs in use?

(2) What spatial characteristics should be continued, which could adapt local sociocultural needs to guide future development? 
In order to achieve local socio-cultural sustainability in historical neighborhood development, the theory of place helps to understand what people's needs should be considered. Butina-Watson and Bentley [9] (p. 6) define place as a 'set of meanings associated with any particular cultural landscape which any particular person or group of people draws on in the construction of their own personal or social identities.' Castello [10] (p. 62) goes further, reinforcing the idea of time and suggesting the importance of heritage by defining place as 'a collection of images that can transmit, at a glance, a suggestive reminder of the historical urban forms the city has acquired all along its evolution' [11]. Although the concept of place is rooted in history, it is continuously changing and is neither static nor uniform [9,12]. Morphologists explain these changes of urban form as typological studies that is cumulative and continuous [13], and consider that continuities of urban form and typological transformation could enhance socio-cultural sustainability and benefit people's satisfaction with living [14-16]. Nurse [17] (p. 33) supports this argument, and states that socio-culture is more than just the manifestations of culture, it is the 'whole social order', the 'whole way of life' and a dynamic process driving sustainable development with the forms of engagement [18]. Therefore, typological approach can be seen as a great tool for defining spatial characteristics and distinctiveness of old and new physical forms based on spatial forms, urban culture and social practice through transformation of the built form that delivers socio-cultural sustainability [19-22].

Recent typological studies in China have not brought much socio-cultural sustainability to light. Gu et al. [23] studied the transformation process of traditional houses in Guangzhou, but focused on the building level. Feng [24] studied the continuities of spatial changes on shikumen (linong) houses with their relationships to layout, plot and street. Chen and Thwaites [14] employed Nanjing as a case in which urban forms were comprehensively studied and described its transformation in relation to a design process for identifying key factors to improve local policy making. Whitehand et al. [7] compared the transformation process of terrace house types and lilong houses between England and Shanghai, and aims to identify whether the latter had been influenced by the former around the late nineteenth and early twentieth centuries.

However, although they have contributed to either large-scale city developments or regeneration of specific urban heritage building typology, none of studies look at what spatial characteristics could adapt to local needs and continue to be applied to future development to enhance socio-cultural sustainability, especially in the context of Beijing, China. In addition, it has always been challenging to identify types through a transformation process, firstly due to the degree of judgement in relation to determining the types of changes to be continued, which is largely subject to the individual researcher's viewpoints [7]. Secondly, it is unclear which types of spatial characteristics and the level of specificity in the investigation that should be considered. Thirdly, there are limitations in empirical studies of spatial types at articulated scales, although many studies focus on individual scales with limited levels of specificity (such as [25]).

Based on discussions above, this paper develops an analytical framework from a physical perspective to define changes of spatial characteristics, which could adapt to the changing of needs to deliver socio-cultural sustainability in historical neighborhoods (vernacular neighborhoods) in Beijing. Six housing types with their spaces and uses were investigated. The research findings contribute to a conceptual and analytical framework for assessing local needs from a physical perspective in order to sustain socio-cultural sustainability; the discontinuity of adaptation of local needs requires more attention to design in order to improve the physical setting to improve socio-cultural sustainability. In addition, the developed analytical framework improves efficiency of analysis in identifications of which spatial characteristics adapt to local needs through physical transformations.

\section{Research Strategies}

This paper proposes three strategies for analysis: 
1. Based on the understanding of place, define key spatial characteristics by employing a typological approach

2. To select cases through identified morphological periods in the neighborhood for analysis

3. To apply the analytical framework to cases that identify continuity of spatial characteristics that could adapt local needs in order to achieve socio-cultural sustainability in historical neighborhoods in Beijing

In the first step, an analytical framework is developed for delivering socio-cultural sustainability in historical development in Beijing by employing a typological approach to define continuity of spatial characteristics. It reviews literature on place $[9,10,12,26-28]$ and seeks to understand links to typological transformation [22,29-32] from a physical perspective to look at how built forms could adapt to local uses and needs.

In the second step, case selections should be representative of their specific historical and geographic characteristics in each morphological period. The identification of residential building types based on different morphological periods is defined by the analysis of the historical transformation period of Beijing from imperial times (before 1911) through the period of Soviet influence (1949-1978) and post Reform period (1978-1990) to the contemporary period (after 1990) [33]. Starting with the building types with their spaces and uses that correspond to imperial traditions and continuing contemporary lifestyles, the case study neighborhood has thus accommodated a greater variety of building types than other areas in Beijing (details refer to analysis in later sections).

The third step implements the analytical framework developed in the first step, to cases identified in the second step. It first studies the neighborhood/ block layout to understand the context, then it analyzes the transformation of cases from its original design to contemporary configurations by employing a typological approach, which identifies the adaptation of changes of local cultural values, social patterns and uses experiences and perceptions following a chronological order. It then compares the degree of changes in the spatial transformation. Based on each spatial characteristic in three morphological layers, this research considers continue, partly continue, and change as evaluation measurements, and a formula is developed in order to calculate the precise value to manage the continuities of these spatial characteristics between cases. Finally, the changes between typological studies as to which spatial characteristics could adapt to local needs and sustain sociocultural sustainability are presented.

\section{Development of Analytical Framework}

In order to achieve the first research goal, developing an analytical framework, it is first important to understand people's needs in place (Table 1), and then to clarify whether these needs are adapted to by physical form through time - this is the key to achieving socio-cultural sustainability. Christian Norberg-schulz [34] suggests that the connection between people and places involves a sort of guardian-spirit that accompanies them from birth to death, a genius loci, that determines their characters, which is identity for a place. Therefore, the relationship between an individual and a place is not just between oneself and one's surroundings, but it has to do with a much deeper process to identify where people create a friendly connection with a particular environment $[2,9,15]$. The process of shaping place is then formed by interactions between people and the physical setting; human actions influence physical settings, and, in return, physical settings stimulate human actions $[35,36]$. 
Table 1. Understanding of needs in place.

\begin{tabular}{|c|c|}
\hline Key Theories to Understand Place & Key Authors \\
\hline Sense of belonging & {$[2,37]$} \\
\hline $\begin{array}{l}\text { Potpourri of memories, interpretations and feelings in relation to the } \\
\text { physical setting }\end{array}$ & [38] \\
\hline Character, uniqueness, distinctiveness and sense of place are evolving & {$[9,26,27]$} \\
\hline Metal registration of physical space 'mind map' & [39] \\
\hline $\begin{array}{c}\text { Set of meanings associated with cultural landscape and } \\
\text { morphological characteristics }\end{array}$ & [9] \\
\hline $\begin{array}{l}\text { Act of embedding meanings in a place, rootedness, memories and } \\
\text { feelings within layers of the physical setting }\end{array}$ & {$[2,9,27,39,40]$} \\
\hline Physical environment and the meanings feelings associates with it & [2] \\
\hline Physical representation of place & {$[10,15]$} \\
\hline Unique places with strong images & [15] \\
\hline $\begin{array}{l}\text { Result of a continuous evolutionary process over time, that includes } \\
\text { socio-economic and political relationships and dynamics }\end{array}$ & {$[12,28,40-44]$} \\
\hline
\end{tabular}

The physical setting needs to adapt to a sense of place, rootedness of feelings and memories and perceptions through urban transformation $[2,9,10,15,37,38]$, while in order to carry out these experiences of use, physical form needs to be developed that corresponds to spatial characteristics through different morphological scales (block, open spaces and buildings) $[9,30]$. Thereby, the place can be simply seen as the result of the interactions between people and the physical setting. The changes to the physical setting need to adapt to people's needs, and to sustain people's needs, the regeneration of physical environment then is as an opportunity to enhance social and economic satisfaction $[45,46]$. These needs are sense of place, sense of belonging, set of meanings and memories and feelings (Figure 1).

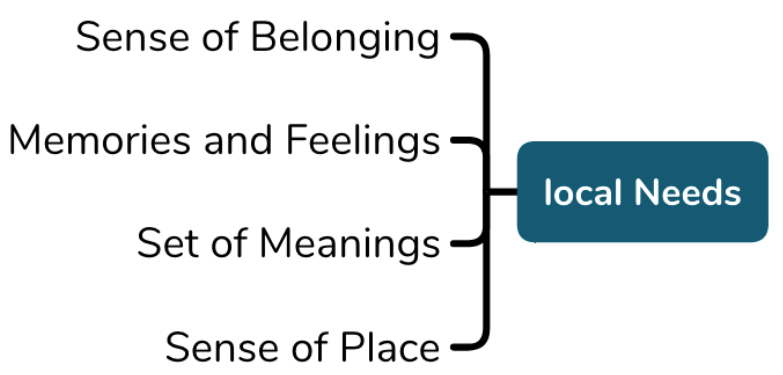

Figure 1. The changing of people's needs in a local place.

However, whether a place is considered as socio-culturally sustainable depends on the level of support or sustainability of the local needs: sets of meanings, sense of belonging, sense of place, and memories from and feelings about a physical setting. The core of socio-cultural sustainability [47] then involves two aspects: futurity and equity. The most often-quoted definition is "(sustainable development) is development that meets the needs of the present without compromising the ability of future generations to meet their own needs"[48] (p. 28). However, this definition lacks consideration of the distinction between equity within a generation, and equity between generations [49]. The needs of local people should be emphasized for the least advantaged in society and a fair treatment of future generations should be ensured [50]. Lim [51] states that culture can be considered a complex matrix of collective experiences and knowledge that formulates a meaning of life, so the values that people hold, the rules and norms they obey and the material objects they use are keys to shaping the built environment into a sustainable place [52,53]. Zetter and Butina Watson [54] go further to say that how people shape their own places and spaces, how 
they adapt local technologies and traditions, and how they deploy innate capacities to adapt cultural precepts to the modern idiom are crucial for sustainability implementations. Therefore, the sets of meanings, sense of place, sense of belonging and memories and feelings that people attach in shaping a place becomes the essence of the local needs, while continually fulfilling these needs for contemporary and future development is the key of the theory of socio-cultural sustainability $[17,55]$.

On the other hand, when we go to study in detail how the transformations of physical settings could adapt local needs to achieve socio-cultural sustainability, the difficulties include how to precisely define which spatial characteristics could continually contribute to uses in public open spaces, and what spatial characteristics of urban forms should be involved, and which can fulfill the local socio-cultural needs. Therefore, the typological approach is a tool because it goes beyond the analysis of physical forms of urban transformation and studies how physical transformation adapts to the changing of needs to understand human actions [22,56]. Moudon [57] states that urban forms can be understood by investigating layout and configuration of forms and spaces in order to clarify the processes of local change- - how forms and spaces are locally built and why. Zetter and Butina Watson [54] argue that physical forms are the products of social consensus and productions of urban forms are the process by which socio-spatial construction take place.

The typological approach aims to provide an understanding of the built environment by examining the historical process of its formation and its hierarchical structure, in order to identify the adaptation to changing needs. It interprets the history of the civilization and its needs for transformation through architecture [58] by analyzing building materials, the structure of buildings and the arrangement of rooms [32]. Then, it uses buildings as elements in order to understand forms and their memories and values, and the meanings beyond. On the other hand, Goodey [59] claims that physical forms should create a sense of belonging and a sense of place that adapts to people's feelings as though individuals belong to the people, to the buildings and to the life there (Figure 2).

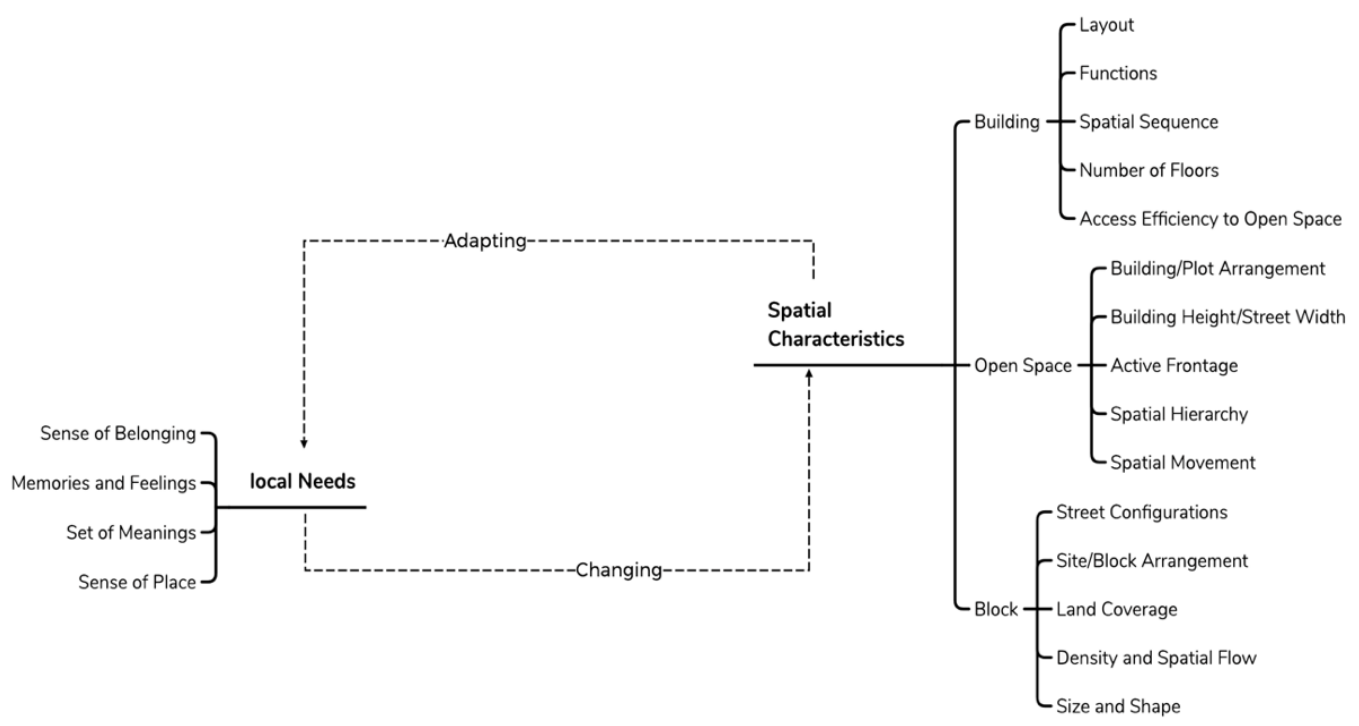

Figure 2. The interrelationship between spatial characteristics and changing of needs.

According to Kropf [30] (p. 112), 'forms found at different levels are identified as types, which are conceived as cultural entities rooted in, and specific to the local process of cultural development' [60]. In Caniggia and Maffei's [29] work, they divided the types into two categories: synchronic and diachronic. In synchronic types, production decreases through time and remains strictly confined to the period in which it was introduced, while the diachronic type undergoes a series of progressive transformations throughout an important time period [32]. Some of types can be observed in different places within a particular time, 
while others are more robust and can survive over consecutive time periods in the same place [32]. The diachronic type is relevant to the typological study, where the types evolve and adapt to the transformation of socio-cultural needs through different historical periods, with the essential spatial characteristics which remain becoming a foundation type [19].

Based on the discussion above, the understanding of an interactional relationship between people and physical setting is clear-in order to design a socio-culturally sustainable place, one must fully understand how people's changing needs associate with continuities of spatial characteristics that deliver socio-cultural sustainability to the local place (Figure 3). In other words, in order to identify what spatial characteristics can be continued in the transformation process, it must comprehensively understand what spatial characteristics continually associate with local uses. Then, the key components of the analytical framework are identified and associated with each morphological scale (building, open space and neighborhood block), and will be used for analyzing cases, identified throughout the morphological period in this research.

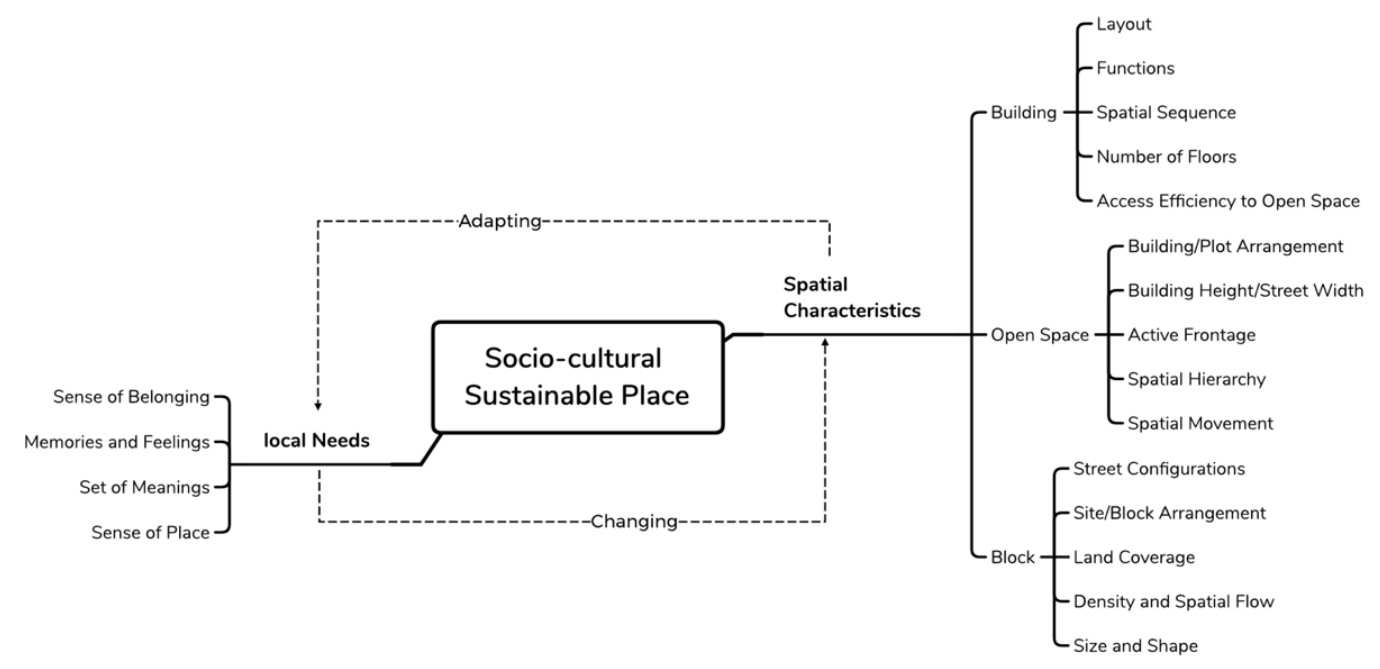

Figure 3. Achievement of socio-cultural sustainability with continuities of spatial characteristics.

In order to understand people's changing needs, and the adaptation of these needs to each spatial characteristic through physical transformation, the study of physical form focuses on three morphological scales: building structures, open spaces, and neighborhood/block layout. The spatial characteristics related to each morphological scale are extracted from theories (Tables 2 and 3). Researching the neighborhood/block layout involves the identification of the relationship of the buildings to the block, size and shape of the neighborhood, land coverage, density and spatial flow and street configurations. The analysis of open space concentrates on building/plot arrangements along public open spaces, building height and width, active front coverage and spatial access patterns and hierarchy between building-building and building-open space. The building structure analysis mainly involves the building layout, functions, number of floors, spatial sequence from entrance to private property and efficiency of access. Figure 4 presents these spatial characteristics and their relationship with each morphological scale that constitutes the framework of adaptation of changing of use in place.

Table 2. Spatial characteristics of typological study.

\begin{tabular}{cc}
\hline Spatial Characteristics & Key Authors \\
\hline Building layout & e.g., $[23,25,31,61-63]$ \\
\hline Building façade & e.g., $[23,31,62,63]$ \\
\hline Number of floors & e.g., $[61]$ \\
\hline Building materials & e.g., $[58,62]$ \\
\hline
\end{tabular}


Table 2. Cont.

\begin{tabular}{cc}
\hline Spatial Characteristics & Key Authors \\
\hline Spatial hierarchy & e.g., $[24,31,64]$ \\
\hline Access efficiency & e.g., $[35,58]$ \\
\hline Open space structures & e.g., $[65,66]$ \\
\hline Plot and block layout, size and shapes & e.g., $[25,30,62,65,67,68]$ \\
\hline Density and land coverage & e.g., $[64,65]$ \\
\hline Spatial relationship between building, plot, open space and block & e.g., $[24,31,62,69]$ \\
\hline Buildings with its relations to open spaces & e.g., $[31,35,64,69]$ \\
\hline Site configurations & e.g., $[67]$ \\
\hline
\end{tabular}

Table 3. The components of Analytical framework.

\begin{tabular}{|c|c|c|}
\hline Layout & Building/Plot Arrangement & Site/Block Arrangement \\
\hline $\begin{array}{l}\text { Public/private zones are strictly } \\
\text { separated, partly separated or not } \\
\text { separated? }\end{array}$ & $\begin{array}{l}\text { Buildings' spatial relationships } \\
\text { (Back-to-back/Side-to-side); } \\
\text { Any set back, front garden, back garden? } \\
\text { Diversity and continuity of buildings } \\
\text { Identical or irregular plots in shape and size? }\end{array}$ & $\begin{array}{l}\text { Open plan or gated? } \\
\text { Any defined site entrance or } \\
\text { boundary? } \\
\text { Spatial Hierarchy }\end{array}$ \\
\hline Functions & Building height/street width & Size and shape \\
\hline $\begin{array}{l}\text { Functions are defined/partly defined/ } \\
\text { not defined }\end{array}$ & $\mathrm{W}=\mathrm{H} / 2 ; \mathrm{W}=\mathrm{H} / 3 ; \mathrm{W}=2 \mathrm{H} ; \mathrm{W}=\mathrm{H}$ & $\begin{array}{l}\text { Size defined by footprint in terms of } \\
\text { accessibility }\end{array}$ \\
\hline Numbers of floors & Active frontage & Land coverage \\
\hline $\begin{array}{l}\text { Original designed/ professional retrofit/ } \\
\text { self-regenerated }\end{array}$ & Active front coverage $(\%) ?$ & $\begin{array}{l}\text { Land construction coverage }(\%) \\
(20 \% \text { - low } / 50 \% \text { - medium/over } \\
70 \% \text {-high }) \\
\text { Numbers of residents }\end{array}$ \\
\hline Spatial Sequence & Spatial hierarchy & Density and Spatial Flow \\
\hline $\begin{array}{l}\text { From the public entrances to private } \\
\text { property; }\end{array}$ & Spatial relationship from public to private & $\begin{array}{l}\text { Location of the case in density areas; } \\
\text { Accessibility efficiency and privacy; }\end{array}$ \\
\hline Access efficiency to open space & Spatial Movement & Street configurations \\
\hline $\begin{array}{l}\text { Total number of steps from private } \\
\text { property to public open spaces; } \\
\text { Spatial transition of access; } \\
\text { Steps from buildings to private property }\end{array}$ & $\begin{array}{l}\text { Total number of steps from private property } \\
\text { to out of neighborhood }\end{array}$ & $\begin{array}{l}\text { Types of roads/streets/paths in site; } \\
\text { Are they mix of pedestrian and } \\
\text { vehicles or separate? }\end{array}$ \\
\hline
\end{tabular}




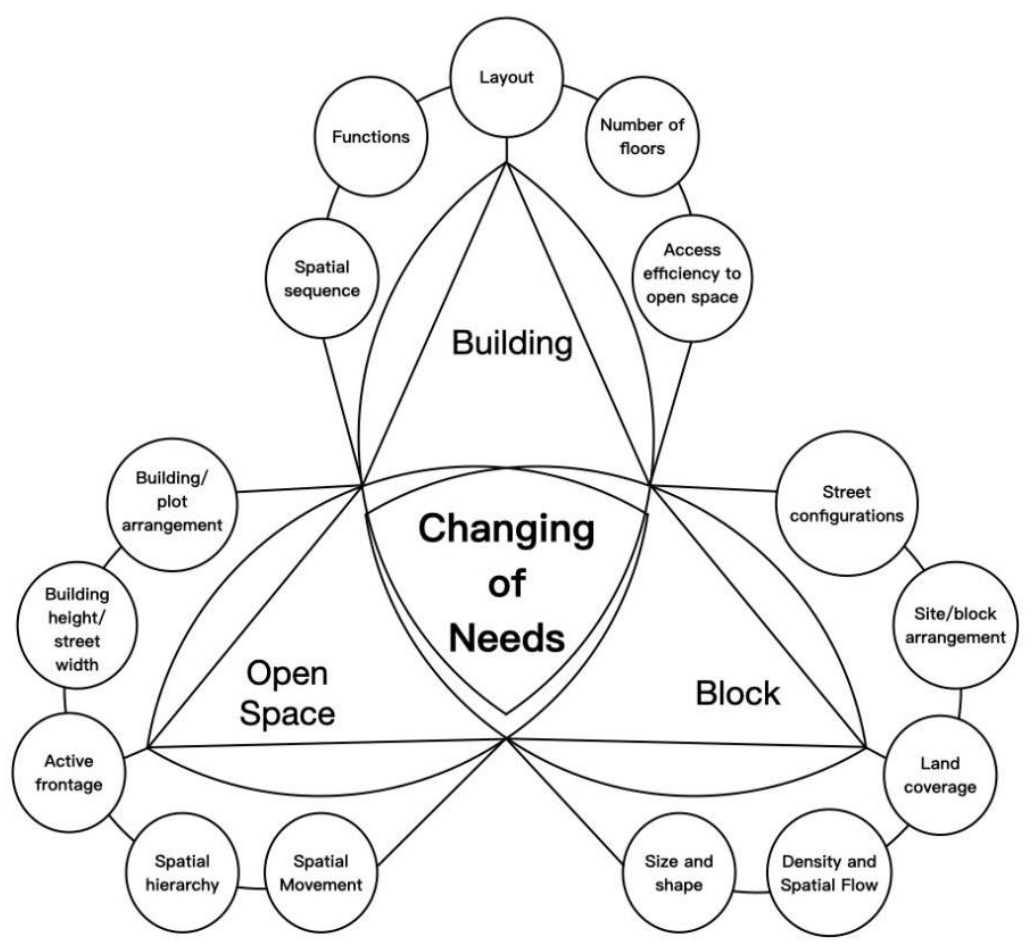

Figure 4. The analytical framework of changing of needs.

\section{Identification of Cases in Transformation of the Neighborhood}

In the second research step, six cases of building typologies are identified in a transformation study of the neighborhood. Qian Yuan'en Si neighborhood (Figure 5) is one of the historical living areas where mainly vernacular but also a variety of other building typologies were free planned after the 1980s [6,69]. During the urban transformation, the main driver of changes in socio-spatial patterns was the shift in formation of the economy from a politically-controlled to a market-driven mechanism [70-72]. Although horizontally the original fabric can still be recognized in the current urban tissue, vertically, the building facades and high-rise plots show dramatic changes (Figure 6). The neighborhood contributes to the overall urban analysis because its built form combined a variety of building types in a vernacular context. Table 4 illustrates four morphological periods in the neighborhood that present transformation of political administration, economic formation, as well as socio-cultural transitions.

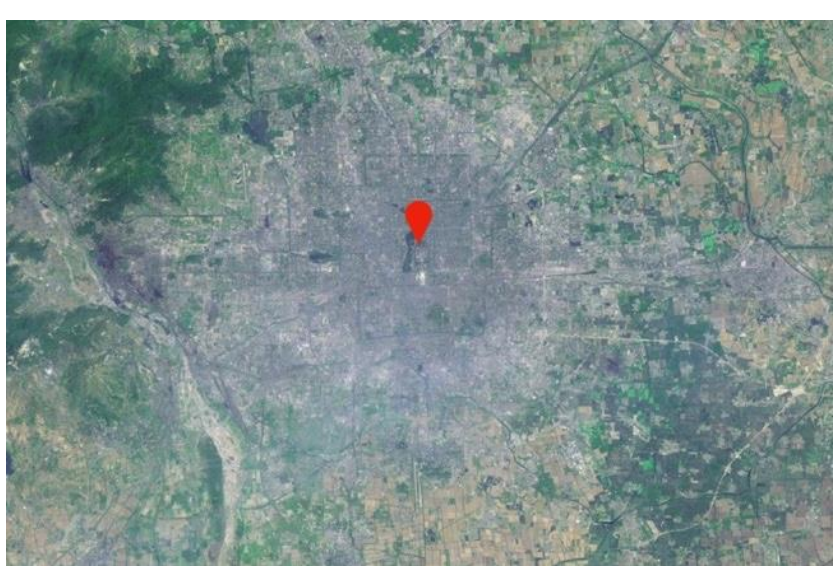

(a)

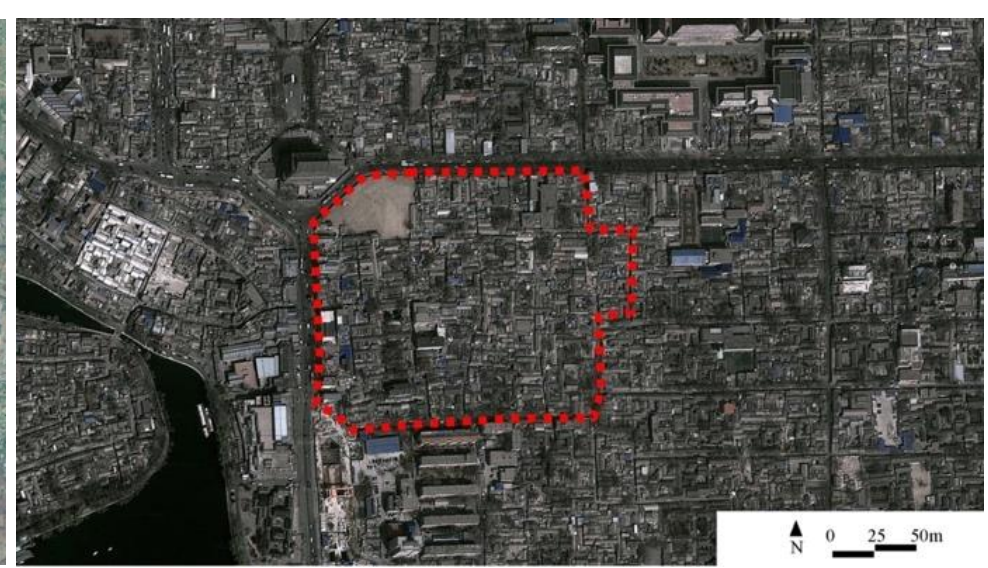

(b)

Figure 5. The location of Qian Yuan'en Si neighborhood. The location of the neighborhood in the city (a), the area of the neighborhood (b). 

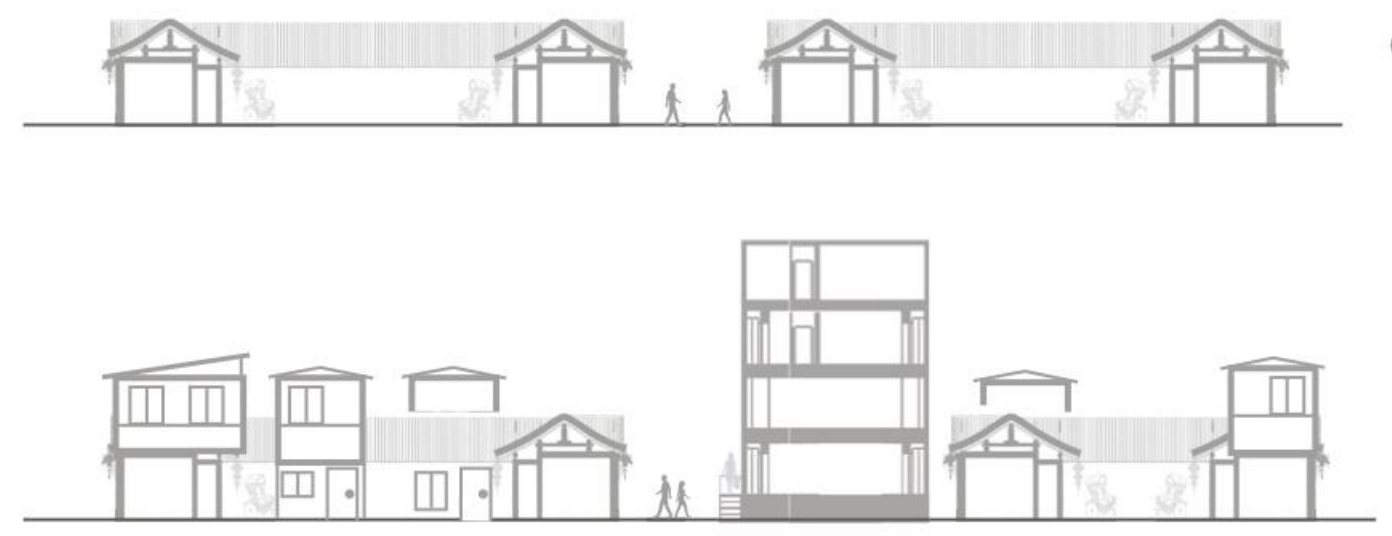

\section{Contemporary \\ Hutong and \\ Courtyard Houses}

Figure 6. The section of Qian Yuan'en Si neighborhood.

Table 4. Changing of building types over time.

\begin{tabular}{cr}
\hline & Morphological Periods and Transforming of Buildings \\
\hline Period 1 & Imperial Period-before 1949 \\
\hline Period 2 & $\begin{array}{r}\text { Traditional housing types, open space structure and block layout, which } \\
\text { address imperial power and social hierarchy in spatial structure. }\end{array}$ \\
\hline Soviet Influence Period-1949-1978
\end{tabular}

The neighborhood came into existence during the Ming dynasty (1368-1644). It was mainly developed during the Qing dynasty (1636-1912) in terms of its morphological tissues. The neighborhood was developed for government institutions and government owned workshops. Thus, the road network within the neighborhood was characterized by one-way roads (cul-de-sacs) designed to have one entrance accessible to the hutong (internal road within the historic block) from the main streets, but all hutongs ended inside in order to maintain a high level of privacy $[73,74]$. The significant change of the neighborhoods started during the Communist period, when there was a movement to remove the 'Four Olds' and the population dramatically increased, and therefore, the function of the neighborhoods completely changed from institutional and residential use to mostly residential use by adapting to the changes in the political and social environment in order to respond to political needs $[8,73,75]$. Thus, the housing types were changed from private to shared houses, and hutong networks were transformed from private design to open access. Before the Post-Reform (1970s), due to population growth, the work-unit based social structure and resources allocation had a serious effect on property allocation, so a movement to reform the political, economic and social structure was formed [75]. However, before the City Planning Law of People's Republic of China (1989) was enacted, due to the dramatically increased population, the residential houses grew organically with occupation of public space and leveled up horizontally in order to meet the enormous demand for living spaces $[8,75]$. Meanwhile, during the transformation process, economic influences started to play an important role because daily commercial needs increased due to population density growth, the changing needs in public space based on uses of automobile, and the lifestyle transit because of cultural effects from globalization, which all meant the area started to engage with urban growth in a more complex way [71] (Figure 7). 


\section{Land Use Transformation of Qian Yuan'en Si Community}

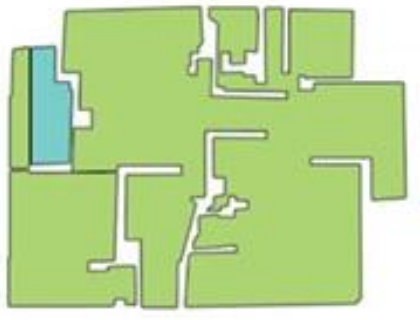

1750

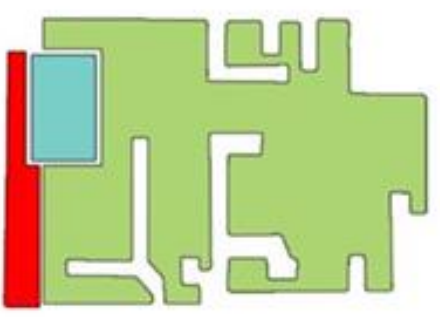

1914

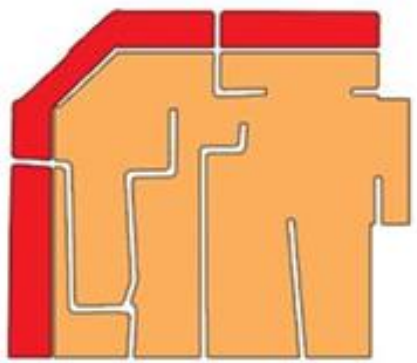

1987

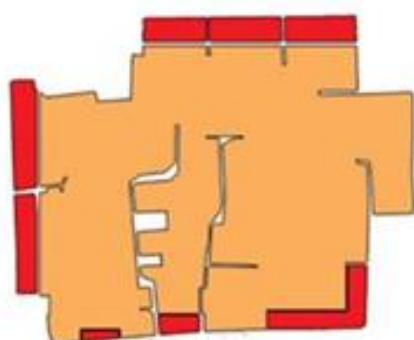

2015

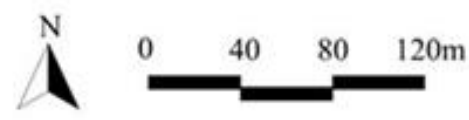

Government institutions

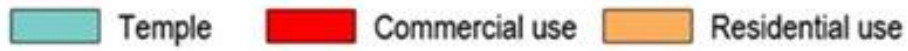

Figure 7. Land use transformation of the neighborhoods.

Through morphological layers for identifying continuities of spatial characteristics that deliver socio-cultural sustainability, Table 5 presents the analysis of a contemporary neighborhood/block structure, which provides current uses in the neighborhood as background and context. In the following sub-sections, each case is identified based on morphological period, and is introduced and analyzed at building scale and open space scale in order to find out changes of spatial characteristics in relation to uses.

\subsection{Imperial Period: Case 1 and Case 2}

The entire neighborhood was developed based on imperial context; traditional courtyard houses and open space networks are commonly discovered in the neighborhoods. However, since 1949, due to changing socio-political ideology, dramatically increased populations and other factors, the traditional courtyard houses were transformed into chaotic-no-yard houses, and one family-owned houses become multi-family occupied residential plots [6,69]. Therefore, its original spatial design is largely changed to fulfill the transitions of access, uses of facilities and ways of living (Figures 8 and 9). Case 1 and 2 are all originally part of traditional courtyard houses, but during urban transformation and socio-political transition, the original inner private yard is built with more rooms to fulfill increased demands for housing, and existing rooms start opening up access directly to the public street (Tables 6 and 7). The differentiations between these cases are: case 1 has occupied public space and built an extension garden as transitional space; and case 2 has converted from residential to commercial uses with transparent doors that visually increase spatial connections between indoor and outdoor. These types of cases represent the largest number of residential houses within the neighborhood. 
Table 5. Neighborhood layout analysis.

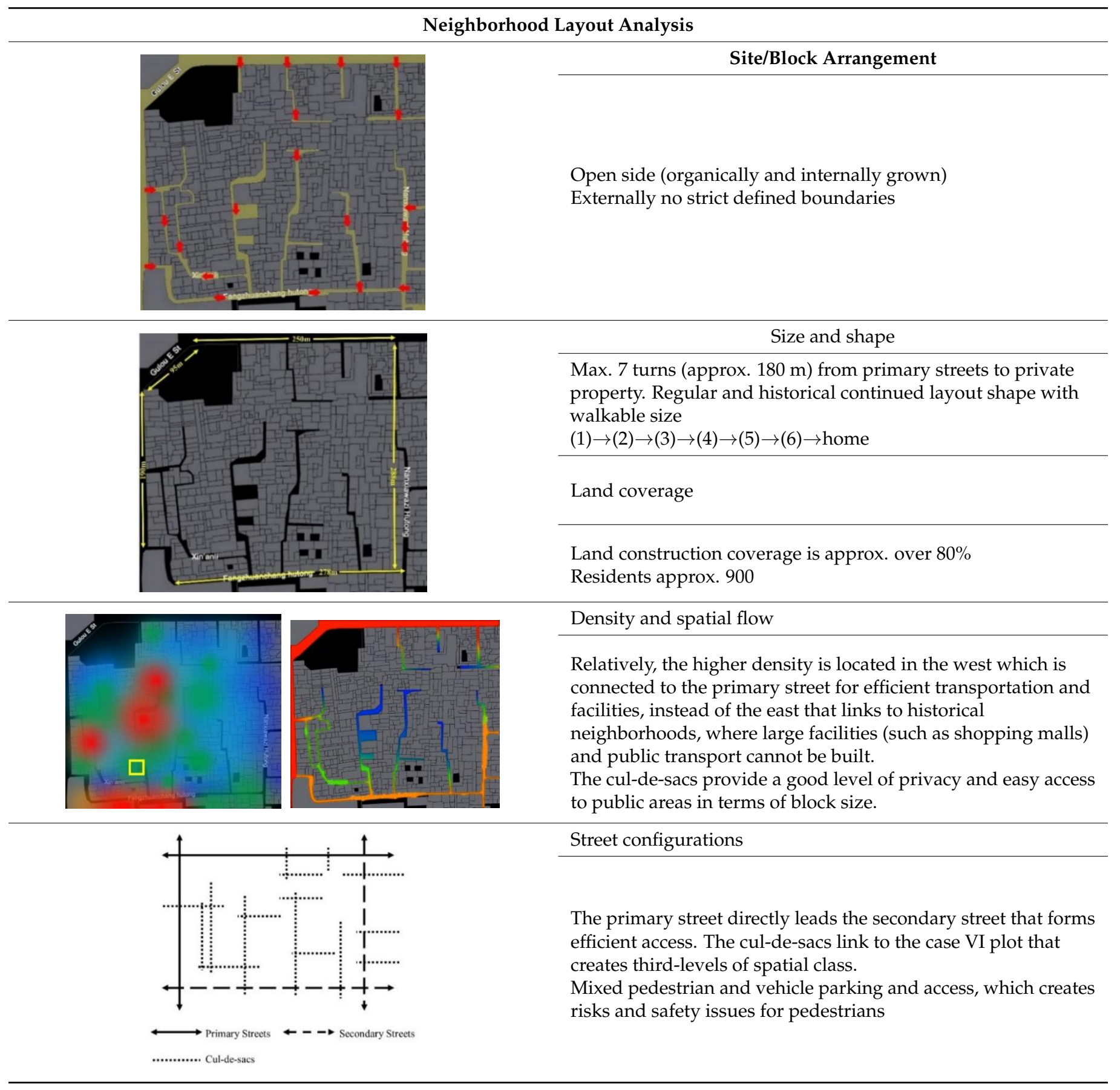




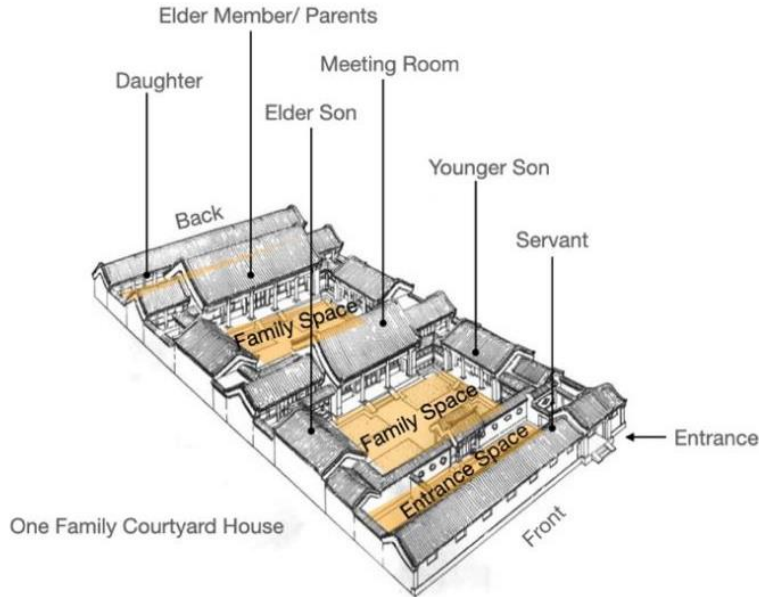

(a)

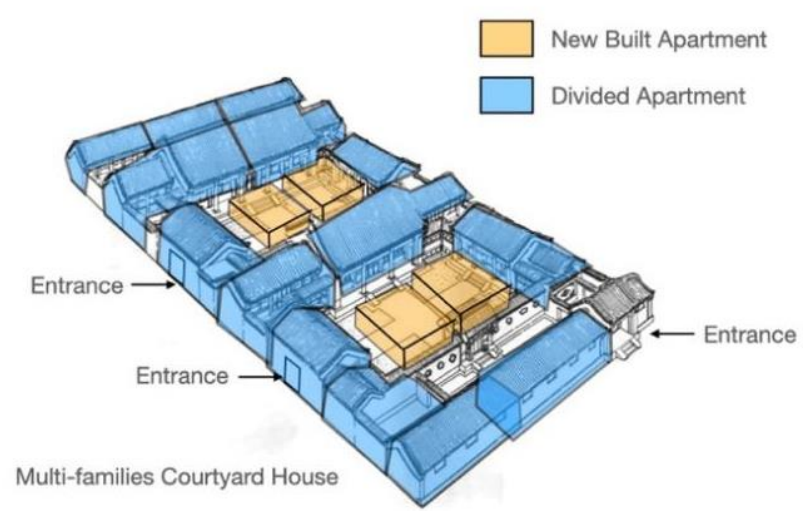

(b)

Figure 8. The transformation of courtyard house. The left subfigure shows the original design of the courtyard house (a), and the right subfigure presents how multi-families occupied the courtyard houses currently (b).

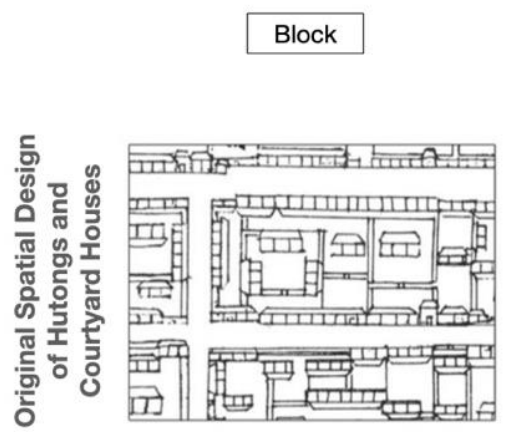

(a)

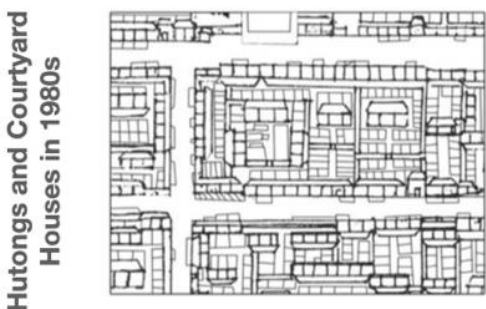

(d)

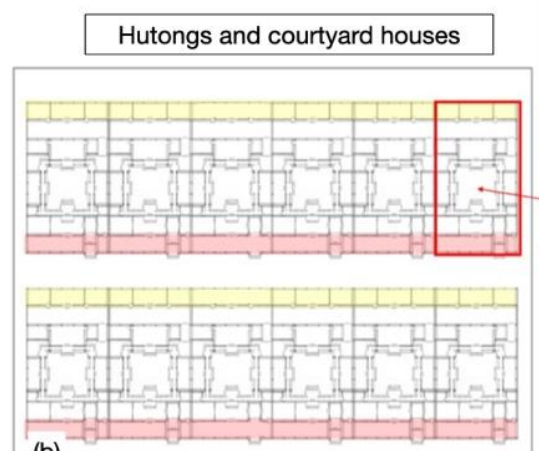

(b)

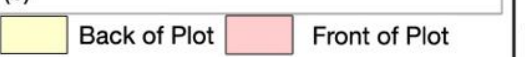

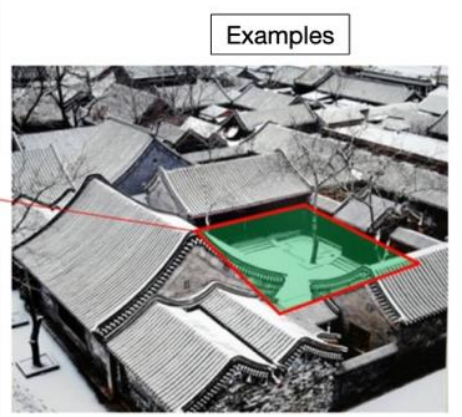

(c)

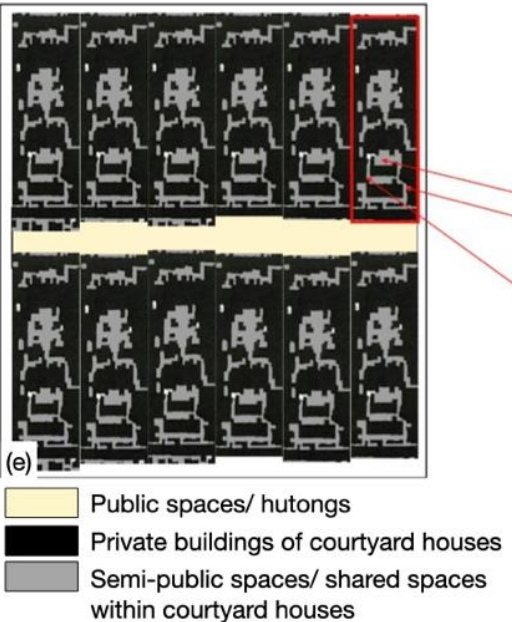

Private spaces in courtyard houses

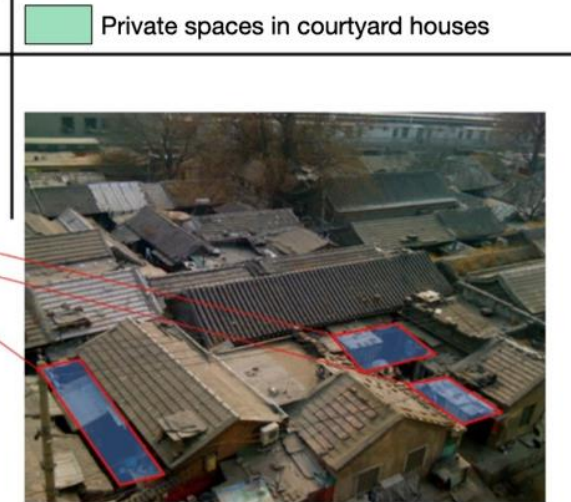

(f)

Figure 9. The transformation of courtyard houses in relation to block. Original spatial design of the block (a), spatial relationship of original courtyard houses and hutong (b), private space in original courtyard house design (c), hutongs and courtyard houses in 1980s (d), spatial changes of courtyard houses and hutongs (e), spaces in courtyard houses after multi-families occupied (f). 
Table 6. Case 1 and Case 2-building structure analysis.

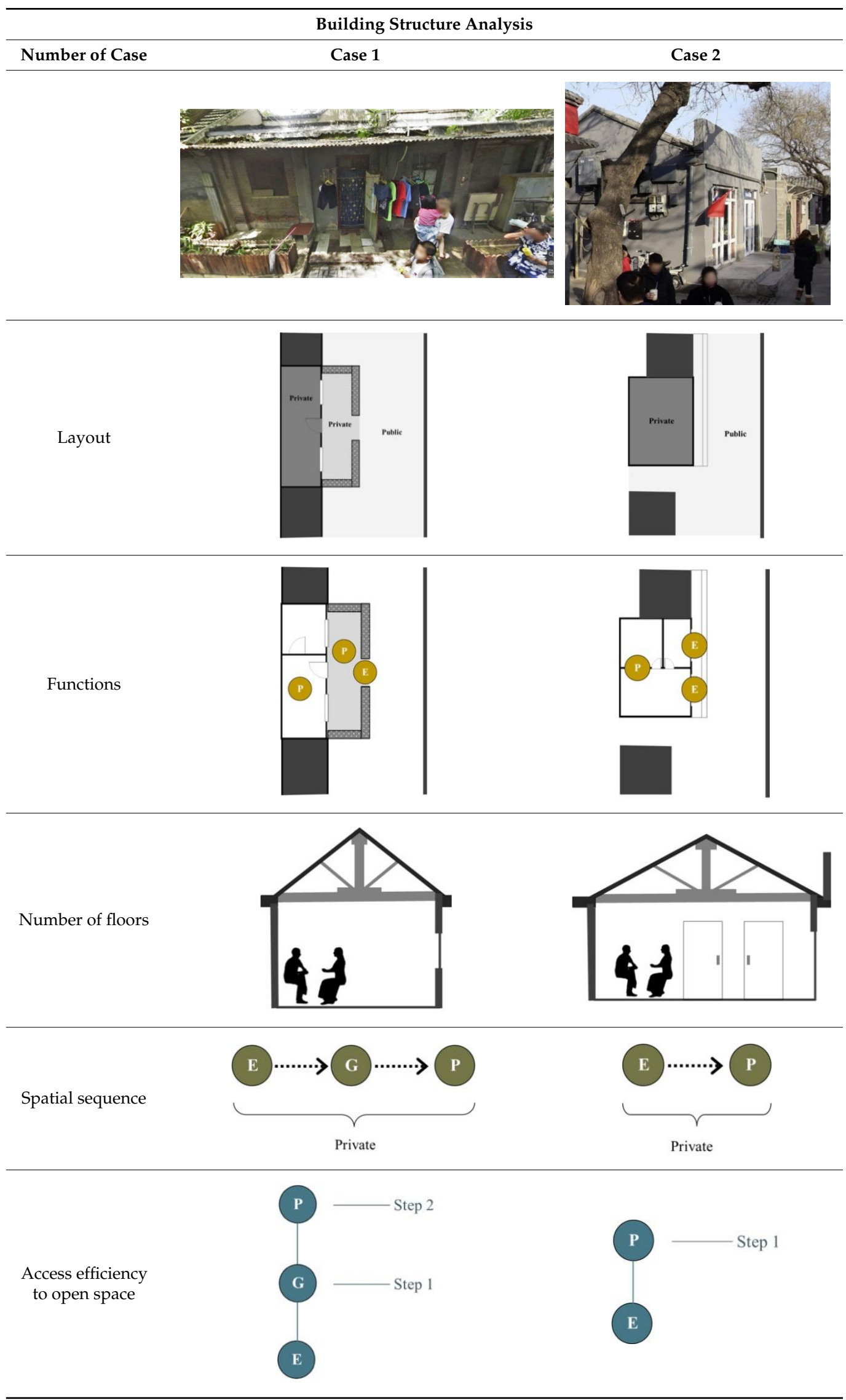


Table 7. Case 1 and Case 2-open space analysis.

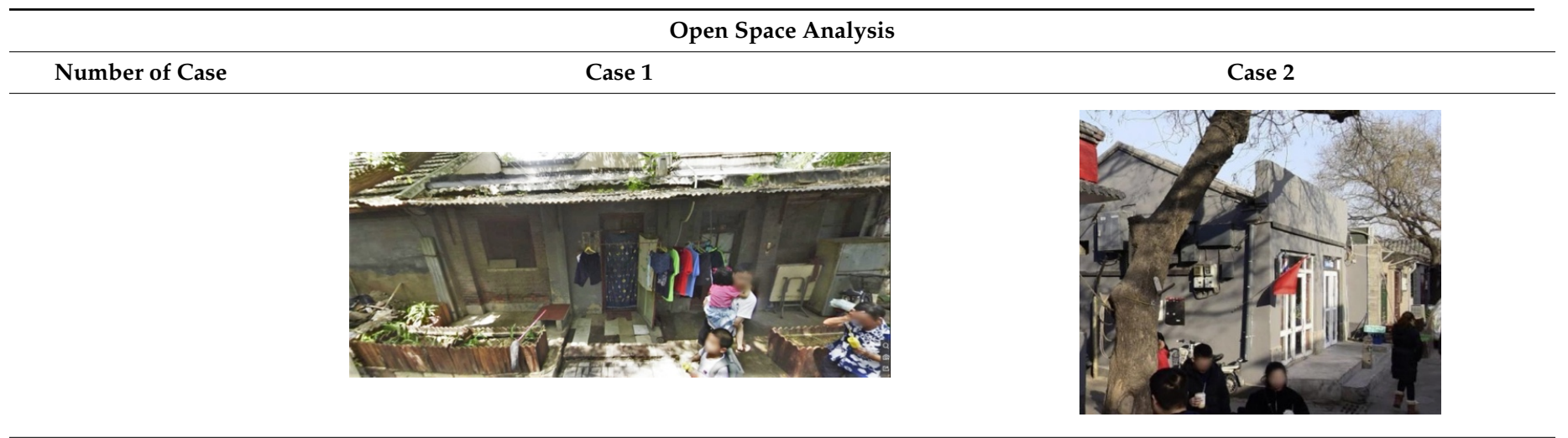

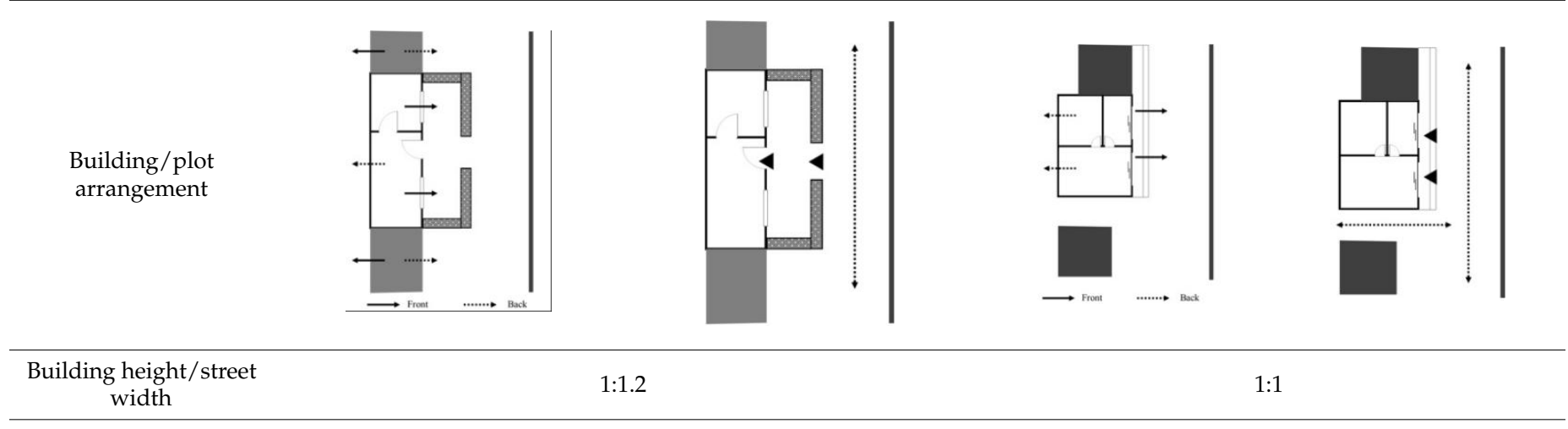

Active front
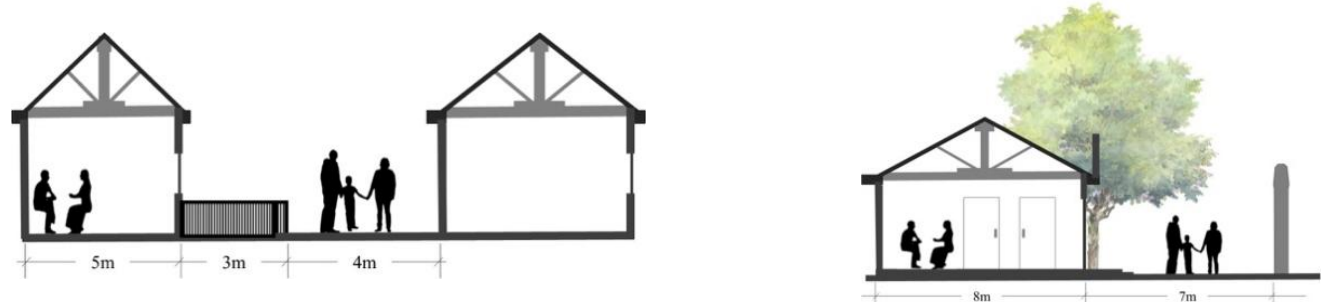

Spatial hierarchy

Spatial movement
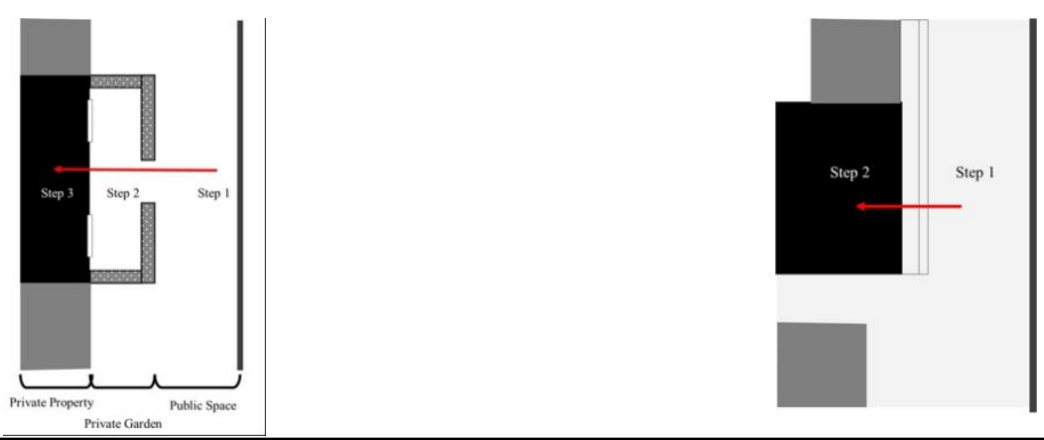

\subsection{Soviet Influence Period: Case 3, Case 4, and Case 5}

In this particular time (1949-1979), soviet socialism and collectivism have seriously influenced not only urban construction and development, but also socio-political ideologies through people's life [75]. During this period, physical urban settings are the major change in China; a large number of traditional buildings were demolished and replaced by soviet style raised buildings, and traditional urban tissue is transited to suit new sociopolitical ideologies, modern facilities (train station, automobile, and motorway) and increased population [75]. The building typologies in this period are mainly presented as two or three storage soviet style buildings, with shared kitchen and bathrooms in each floor. However, in contemporary use (Tables 8 and 9), many of these buildings are regenerated; the representative examples are: 
case 3-the original building has extended its height and length with changed façade to adapt to increased populations and transitions of needs to suit new lifestyles and technologies such as automobile use; case 4-develops its own semi-private space for improving activity needs and parking; and case 5-keeps its original design.

Table 8. Case 3, Case 4 and Case 5-Building structure analysis.

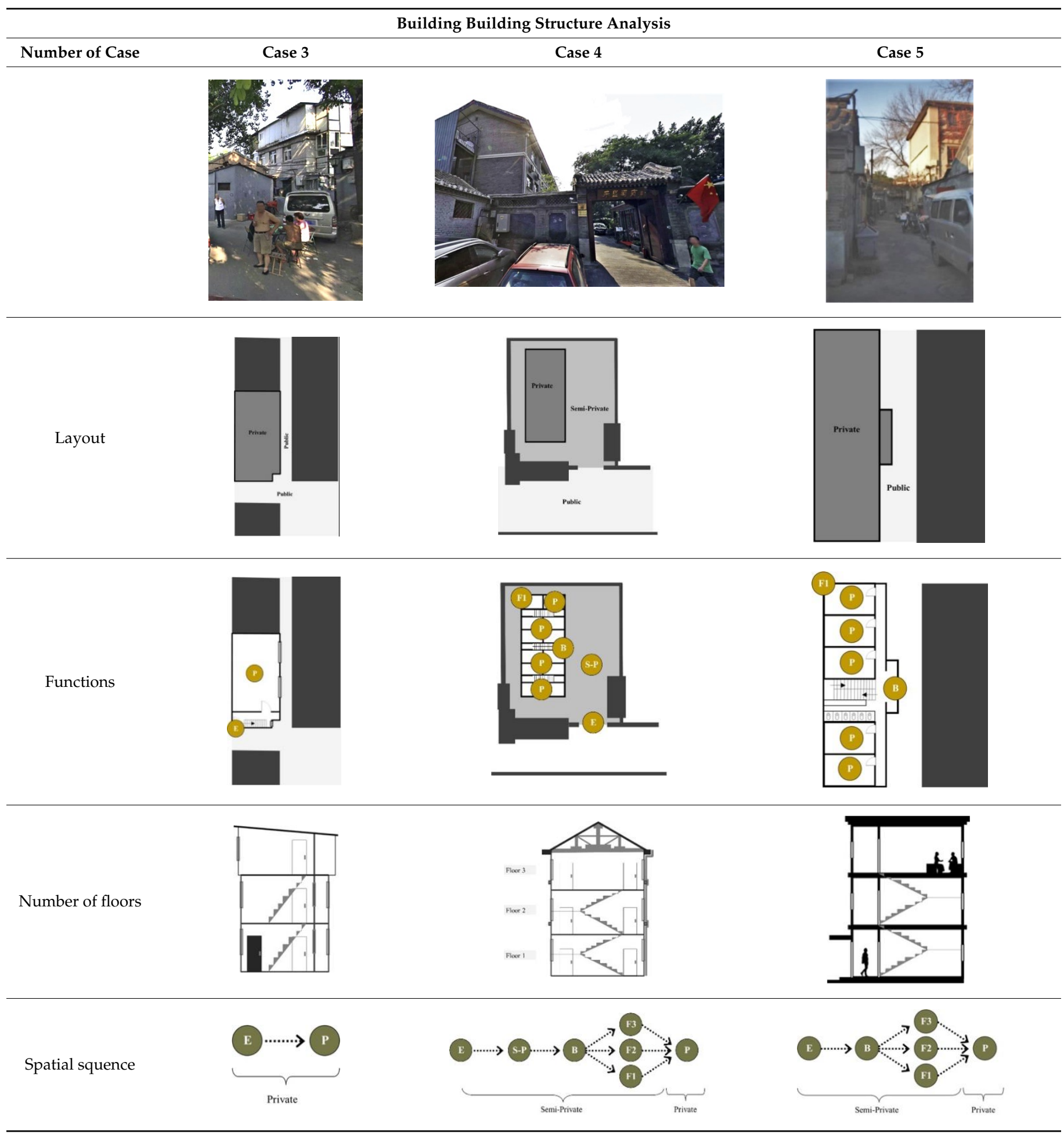


Table 8. Cont.

\begin{tabular}{lllll}
\hline \multicolumn{5}{c}{ Building Building Structure Analysis } \\
\hline Number of Case & Case 3 & Case 4 & Case 5 \\
\hline $\begin{array}{c}\text { Access efficiency } \\
\text { to open space }\end{array}$ & E & Step 1 & & \\
\hline
\end{tabular}

Table 9. Case 3, Case 4 and Case 5-open space analysis.

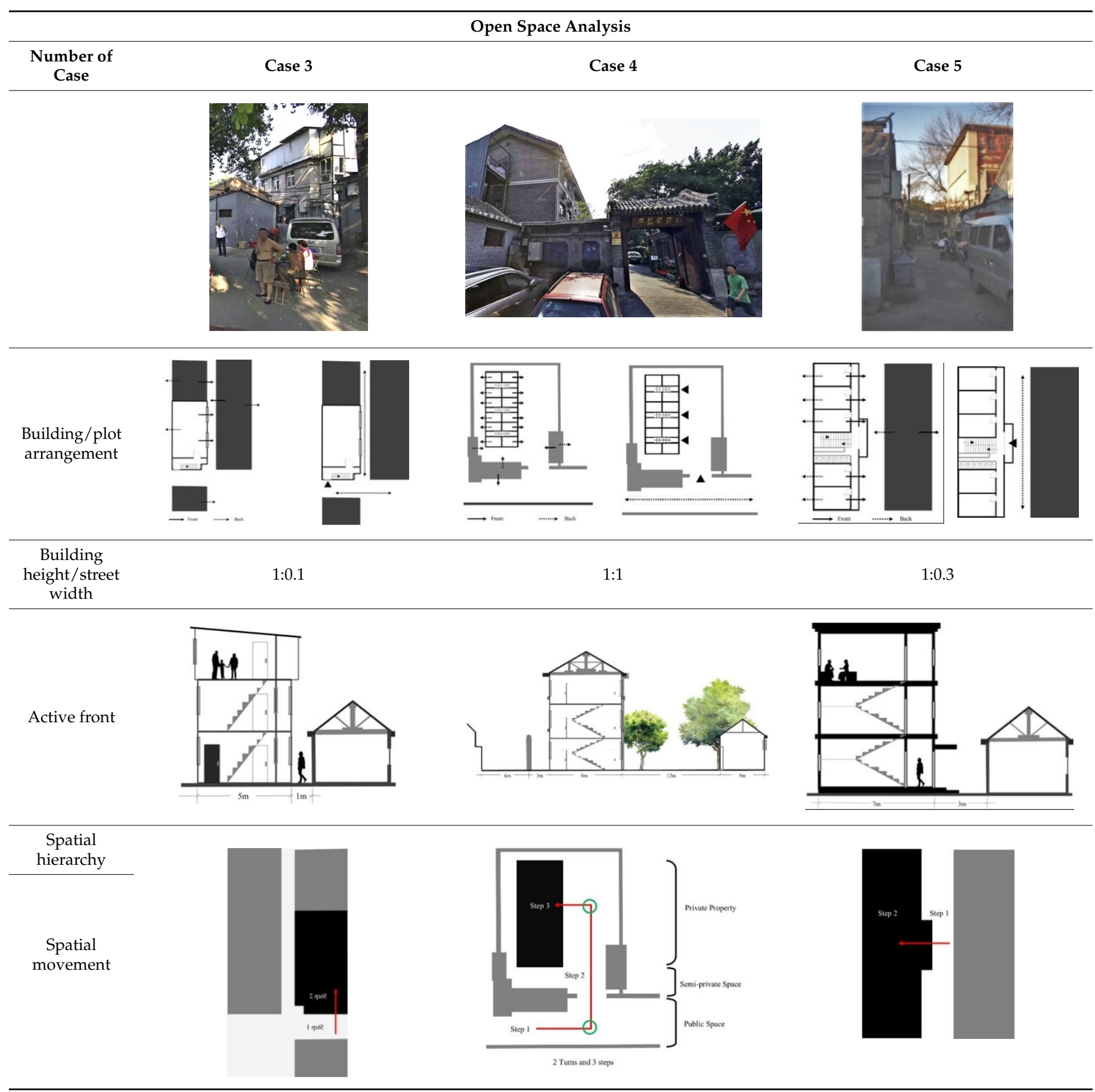




\subsection{Post-Reform and Contemporary Period: Case 6}

Since 1978, the country has transformed from a planned economy to an open market, and socio-political and economic ideology is changing under the influence of globalization. Functional apartments with a good level of privacy have been introduced since this time, and the living style has been transformed from shared facilities (e.g., bathroom and kitchen) to privately owned [75] (Figure 10). Case 6 is an example to present the design of the building in this period (Table 10). The building is international style with four storages, and due to lack of professional design with appropriate spatial relation to the surroundings, the spaces between nearby houses are extremely narrow. In contemporary use, residents occupied part of public areas and built extensional rooms as storage for bicycle parking at the beginning, and pure storage later.

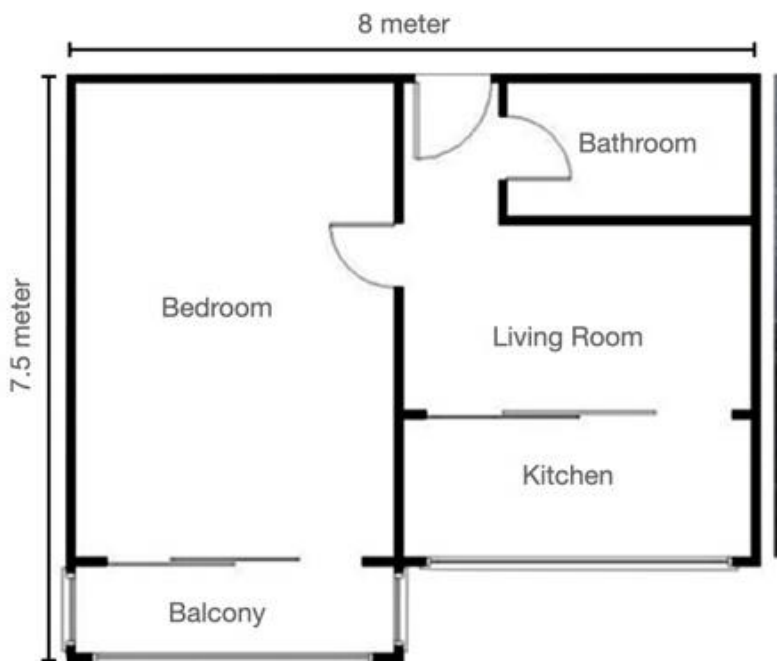

(a)

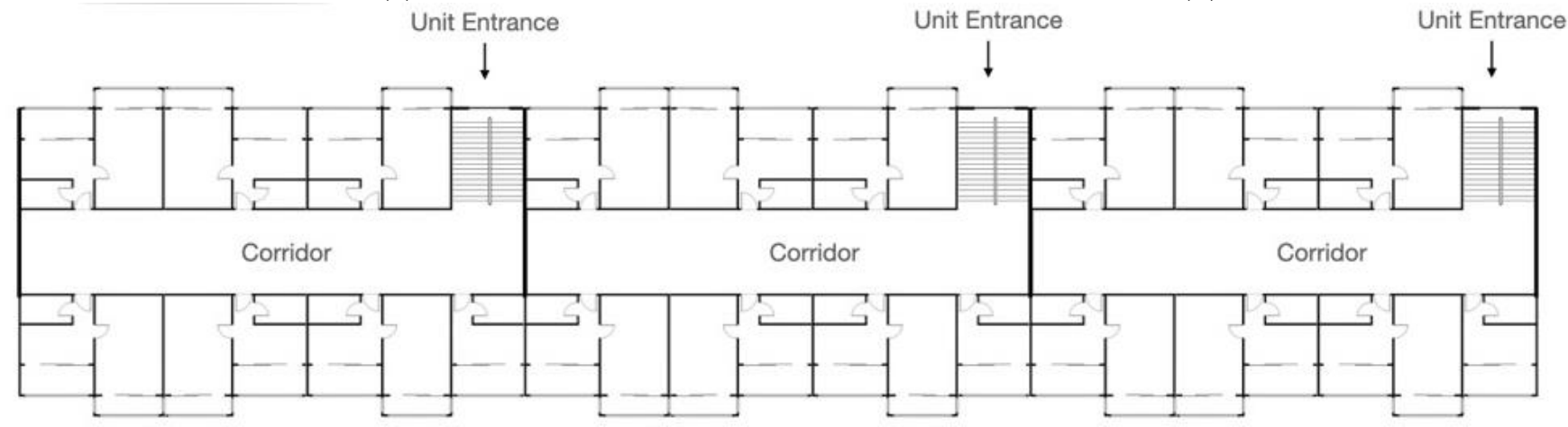

(c)

Figure 10. Modern apartment and its layout. Top left image shows the apartment layout (a); top right image presents the building design (b); and down image illustrates the floor plan of the building (c).

Table 10. Case 6-building structure analysis and open space analysis.

\begin{tabular}{cc}
\hline Building Structure Analysis & Open Space Analysis \\
\hline Case 6 & Case 6 \\
\hline
\end{tabular}


Table 10. Cont.

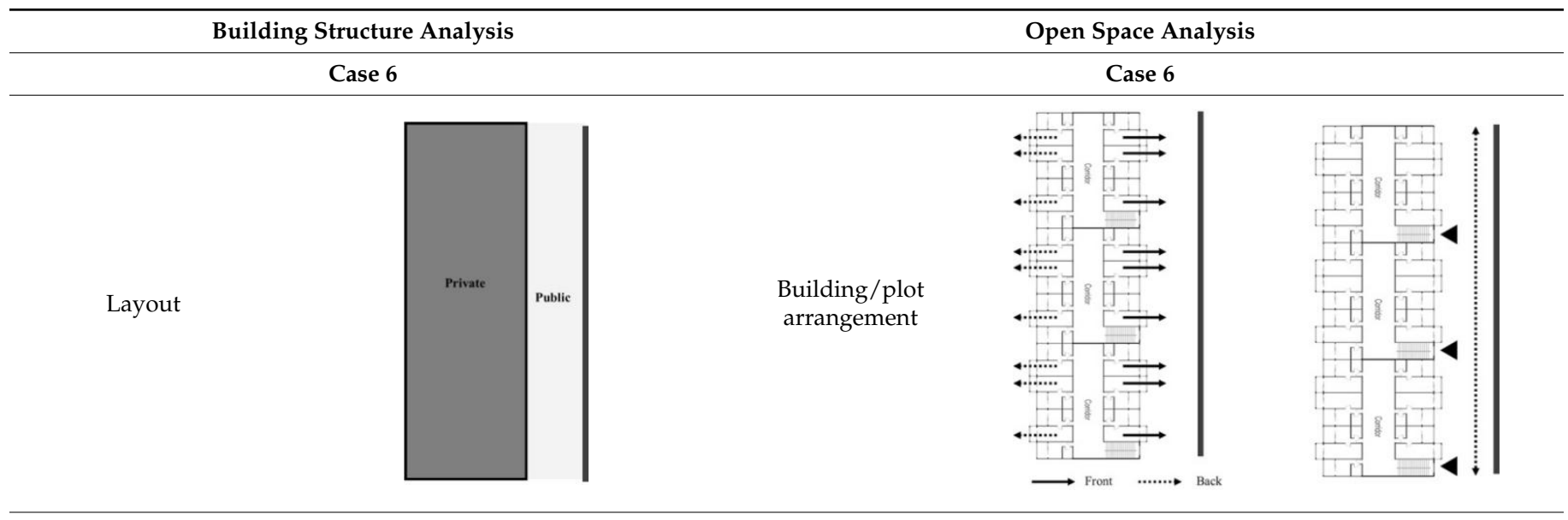

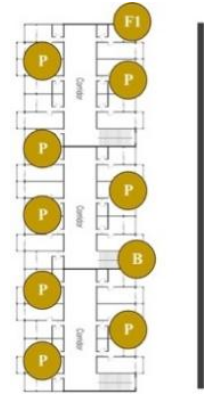

Building height/street

Functions width

Number of floors
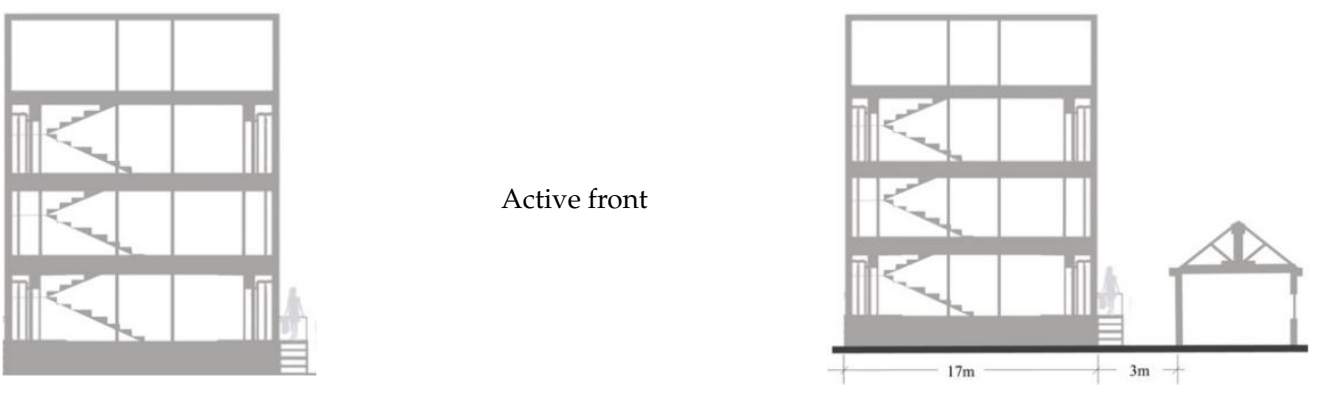

Spatial sequence

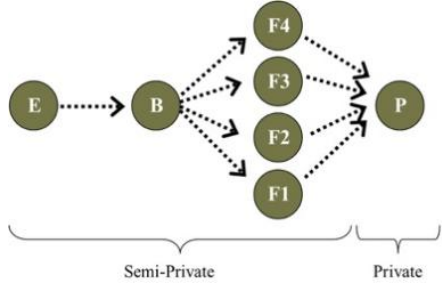

Spatial hierarchy

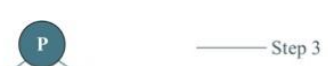

Active front

Access efficiency to open space
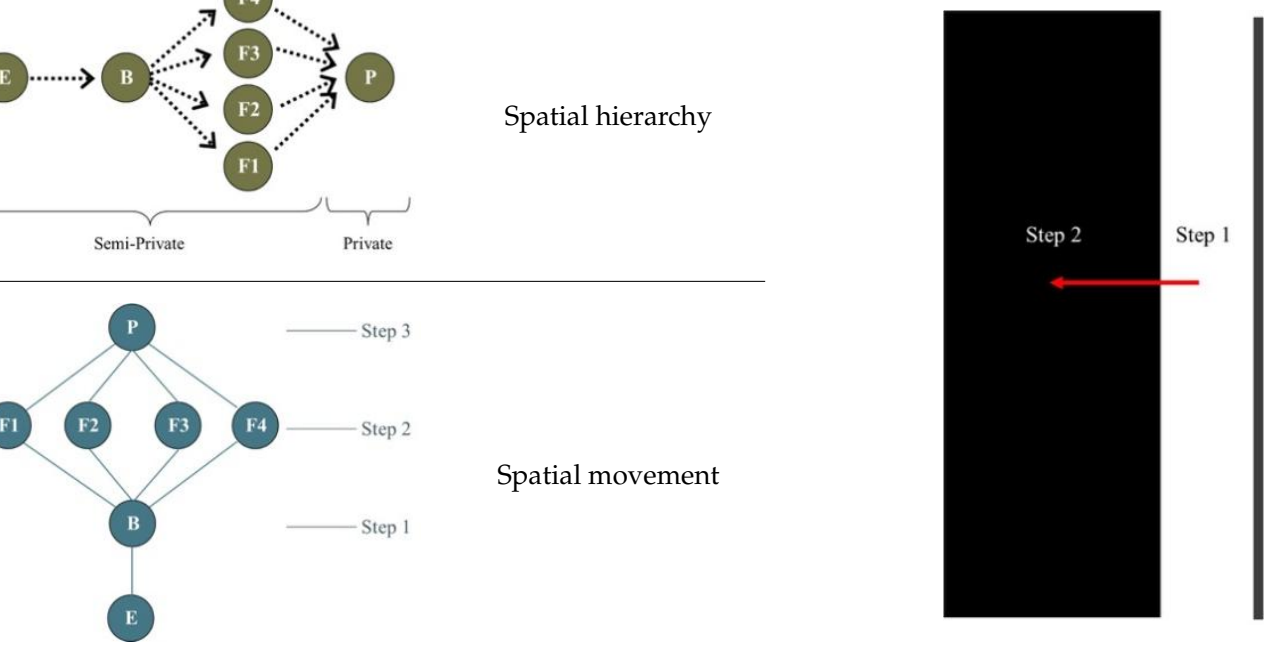

In total, six cases were identified based on morphological transformation analysis to cover all types of buildings and influences on the open spaces in the neighborhood (Figure 11). 


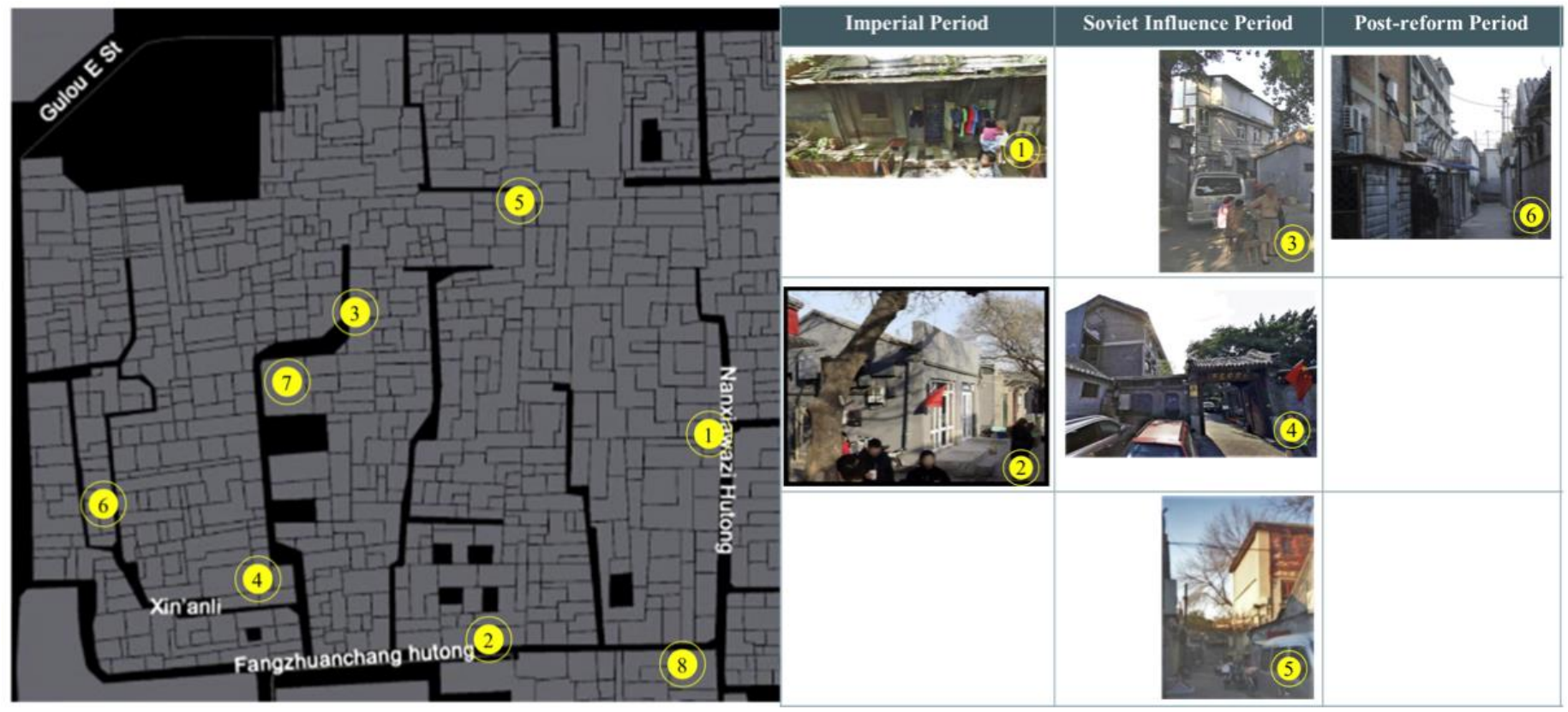

Figure 11. Locations of cases and their categories.

\section{Analysis of Changes of Spatial Characteristics between Cases}

In this section, a third research strategy is implemented, in which the analytical framework is continually employed to analyze the continuities of spatial characteristics between cases. Based on the analysis of all six cases, the study identified a degree of continuity of spatial characteristics in building structure and open space level in chronological order, which illustrates which spatial characteristics are continued, partly continued or changed from the previous morphological period to the next one. It is then clear to see, based on the transformation of socio-political and economic ideology, how different types of forms have changed local needs, and how local needs have changed these spatial characteristics. During the process, many spatial characteristics are discontinued due to transitions of needs, but it also shows available spatial characteristics that can be continued to sustain socio-cultural sustainability in future development.

As explained above, in the third research step a method of calculation is developed as a measurement to evaluate the degree of continuity and changes of spatial characteristics: continue, partly continue and change. The formula is developed in a two-step process: calculation of originality of spatial characteristics, and calculation of continuity of these spatial characteristics. As shown in Figure 12, each case in each spatial characteristic first needs to define the originality of its typology compared to its original design, whether it maintains original, or partly original or changed to another type (in Tables 11 and 12), to define the spatial characteristics in contemporary use. Then, formula 1 is used to calculate the score of originality (Represented by $O$ ) and justify the category of spatial characteristics based on the originality of each case (Tables 11 and 12). Secondly, when the spatial characteristics in contemporary uses are defined, the originality score of calculation from formula 1 is used to clarify its categories: the clear cycle in Tables 13 and 14 represents the spatial characteristics of each case maintained in the original, grey cycle symbols are partly original, and black cycle means the physical characteristics have changed. Each originality score is used in formula 2 to calculate the continuity of these spatial characteristics between cases. The analysis results (Tables 13 and 14) are then clear-each physical characteristic clearly presents the form of transformation at different morphological layers through different periods. 


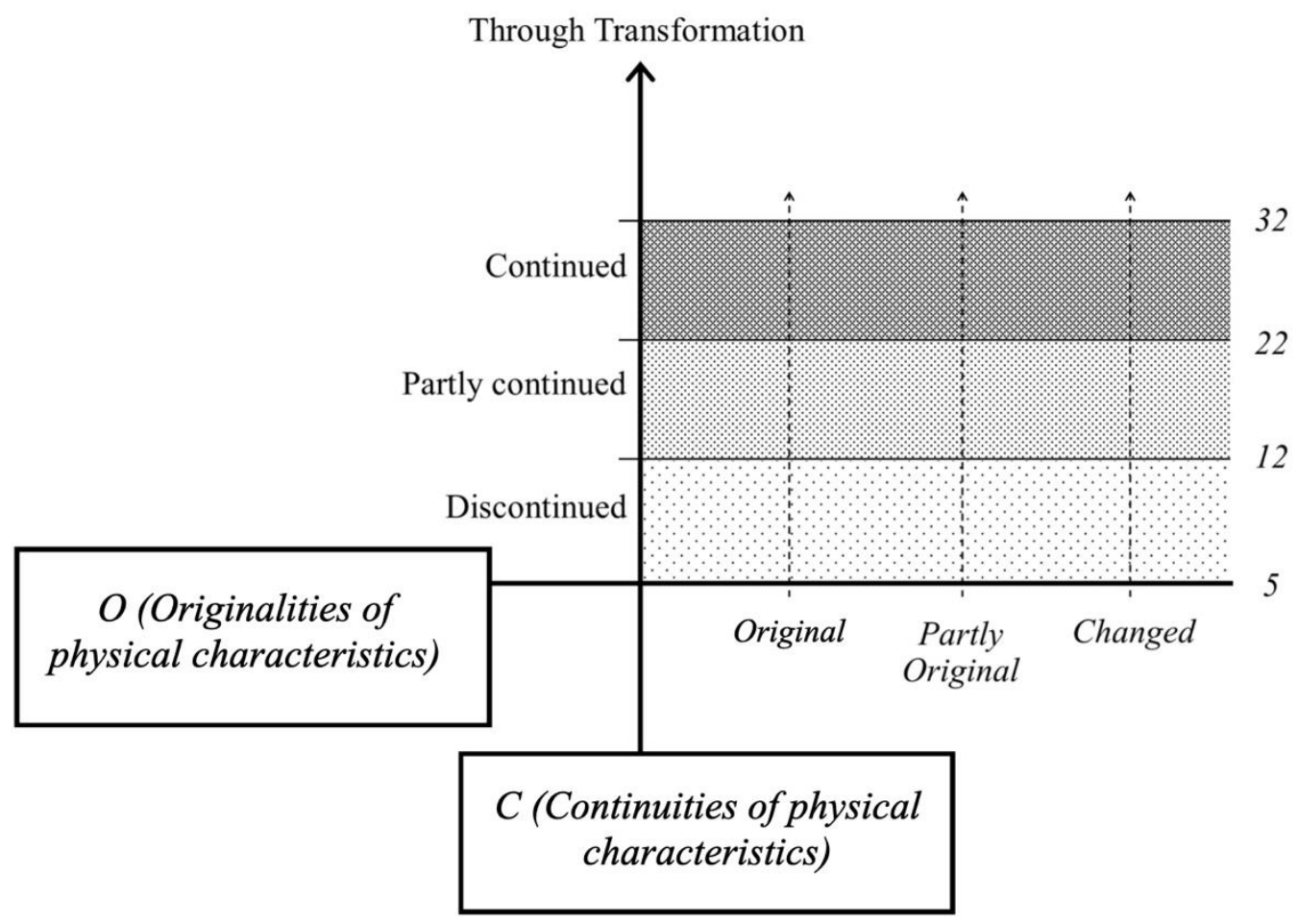

Figure 12. The interrelationship between originalities of physical characteristics $(O)$ and continuity of spatial characteristics $(C)$.

Table 11. Calculation results of originality between cases in building analysis by using formula.

\begin{tabular}{|c|c|c|c|c|c|c|}
\hline \multirow{3}{*}{$\begin{array}{l}\text { Building } \\
\text { Analysis }\end{array}$} & \multicolumn{6}{|c|}{ Morphological Periods } \\
\hline & \multicolumn{2}{|c|}{ Period 1} & \multicolumn{3}{|c|}{ Period 2} & \multirow{2}{*}{$\begin{array}{c}\text { Period } 3 \\
\text { Case } 6\end{array}$} \\
\hline & Case 1 & Case 2 & Case 3 & Case 4 & Case 5 & \\
\hline Layout & 9 & 3 & 9 & 9 & 9 & 9 \\
\hline Functions & 6 & 3 & 9 & 9 & 9 & 9 \\
\hline Number of floor & 6 & 6 & 3 & 9 & 9 & 9 \\
\hline Spatial sequences & 9 & 3 & 9 & 9 & 9 & 9 \\
\hline Access efficiency & 6 & 3 & 9 & 9 & 9 & 9 \\
\hline
\end{tabular}

Table 12. Calculation results of originality between cases in open space analysis.

\begin{tabular}{ccccccc}
\hline & \multicolumn{5}{c}{ Morphological Periods } \\
\cline { 2 - 7 } Open Space Analysis & \multicolumn{2}{c}{ Period 1 } & & Period 2 & Period 3 \\
\cline { 2 - 7 } & Case 1 & Case 2 & Case 3 & Case 4 & Case 5 & Case 6 \\
\hline $\begin{array}{c}\text { Building/plot } \\
\text { arrangement }\end{array}$ & 8 & 8 & 5 & 9 & 9 & 9 \\
\hline $\begin{array}{c}\text { Building height/street } \\
\text { width }\end{array}$ & 6 & 9 & 6 & 9 & 9 & 6 \\
\hline Active frontage & 6 & 9 & 6 & 9 & 9 & 6 \\
\hline Spatial hierarchy & 9 & 3 & 9 & 9 & 9 & 9 \\
\hline Spatial movement & 6 & 3 & 9 & 9 & 9 & 9 \\
\hline
\end{tabular}


Table 13. Building structure analysis results.

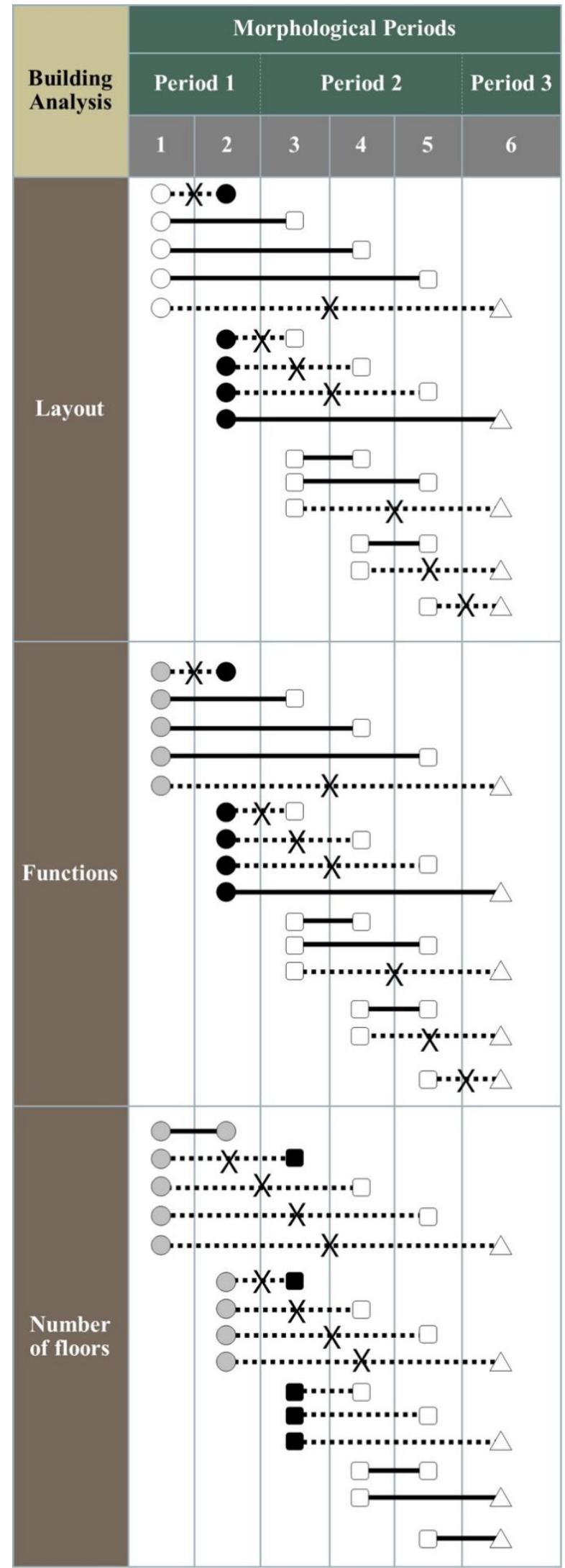

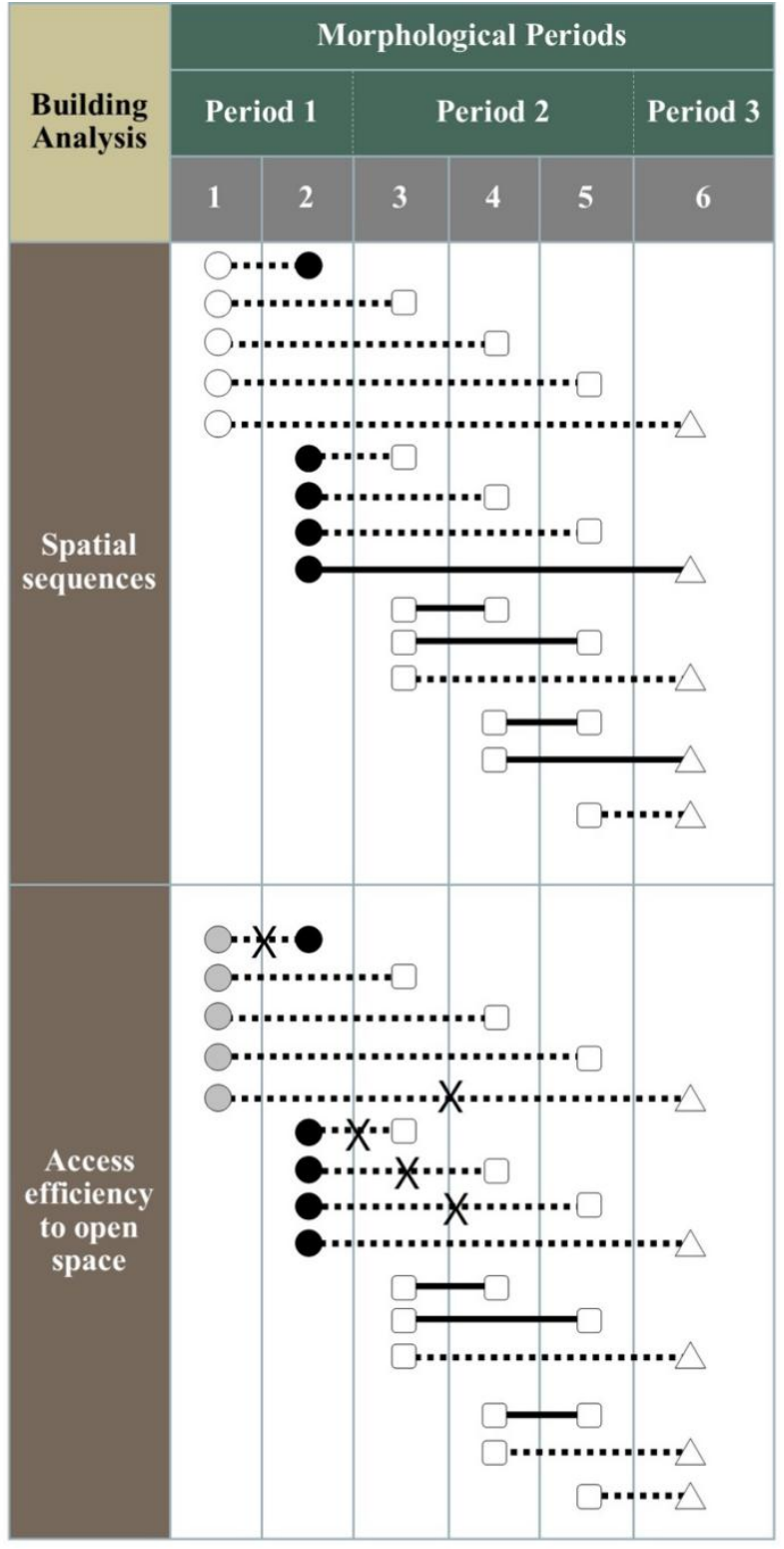

Physical characteristic with original identity from Period 1

- Physical characteristic with partly original identity from Period 1

- Physical characteristic has changed original identity from Period 1

$\square$ Physical characteristic with original identity from Period 2

$\square$ Physical characteristic with partly original identity from Period 2

- Physical characteristic has changed original identity from Period 2

$\triangle$ Physical characteristic with original identity from Period 3

$\triangle$ Physical characteristic with partly original identity from Period 3

- Physical characteristic has changed original identity from Period 3

- Physical characteristic continues from previous type

........ Physical characteristic partly continues from previous type

....... Physical characteristic discontinues from previous type 
Table 14. Open space analysis results.
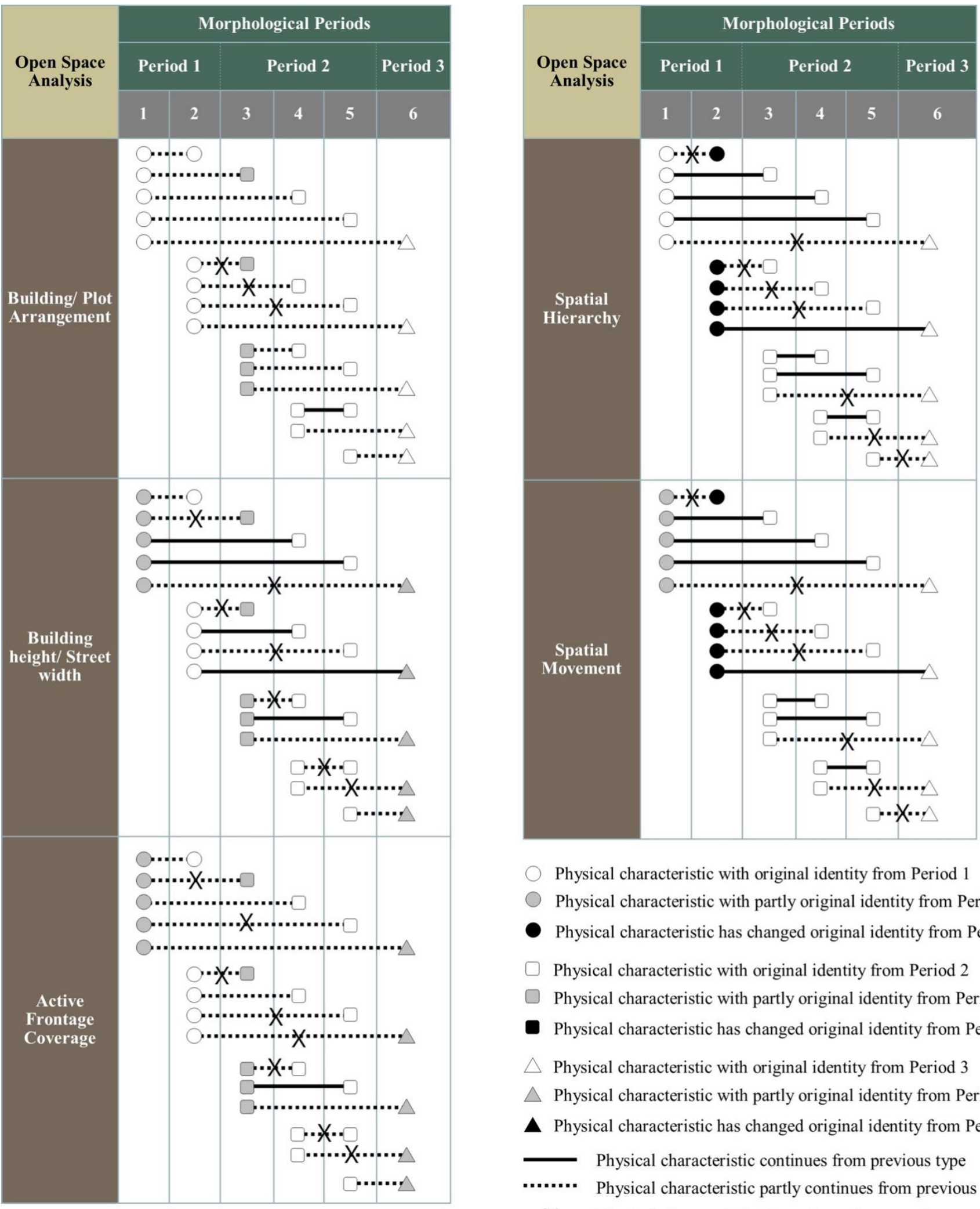

Physical characteristic with original identity from Period 1

Physical characteristic with partly original identity from Period 1

- Physical characteristic has changed original identity from Period 1

$\square$ Physical characteristic with original identity from Period 2

$\square$ Physical characteristic with partly original identity from Period 2

- Physical characteristic has changed original identity from Period 2

$\triangle$ Physical characteristic with original identity from Period 3

$\triangle$ Physical characteristic with partly original identity from Period 3

A Physical characteristic has changed original identity from Period 3

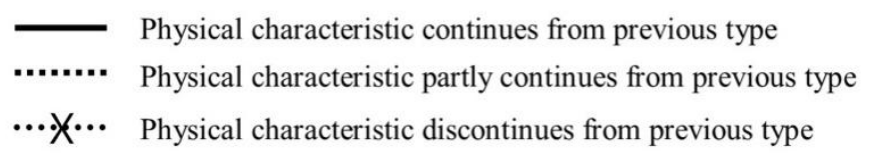


The continuity score $(O)$ is calculated using the following formula:

$$
O=k \times \frac{1}{m} \times \sum_{j=1}^{\mathrm{m}} o_{\mathrm{r} j}
$$

The $O$ represents the originality of physical characteristics, $k$ is a constant number equal to $3, m$ represents the total number of sub-items in each spatial characteristic, $o$ represents the originalities of the sub-item, and $r$ represents the score of originalities of the sub-item. When $r=3$, it means the case maintains its original design, when $r=2$, it means the case partly changed its design, and when $r=1$, it means the case has completely changed its original design. $J$ represents the number of sub-item in sequence in each spatial characteristics.

Higher ' $O$ ' scores indicate original design, while lower ' $O$ ' scores represent change. The maximum possible score is thus $9[=3 \times 1 / 6 \times(3+3+3+3+3+3)]$ if all spatial characteristics are maintained in its original formation; while the minimum possible score is $3[=3 \times 1 / 1 \times(1)]$ if all spatial characteristics are changed. Therefore, If $7 \leq C<9$, the originality of the physical characteristic is maintained as original; if $5 \leq C<7$, the originality of the physical characteristic is defined as partly original; if $3 \leq C<5$, the originality of the physical characteristic is indicated as changed.

By using the score of originality, Formula 2 calculates the score of continuity of spatial characteristics $(C)$.

When the analysis results between cases present continuity, use the formula:

$$
C=\left(N_{c}+|\bar{O}|\right)
$$

When the analysis results between cases present partial continuity, use the formula:

$$
C=\left(N_{p c}+|\bar{O}|\right)
$$

When the analysis results between cases present discontinuity, use the formula:

$$
C=\left(N_{d}+|\bar{O}|\right)
$$

$C$ represents the continuity of spatial characteristics, $N_{c}$ represents continue and equals 25 , $N_{p c}$ presents partly continue and equals $15, N_{d}$ means discontinue and equals 5 and - represents interrelations between two compared cases.

Higher ' $C$ ' scores represent continuity of physical characteristic, while lower " $C$ " scores indicate discontinuity of physical characteristic. The maximum possible score is therefore $31[=25+|9-3|]$ if all spatial characteristics are continued between cases; while the minimum possible score is $5[5+|9-9|]$ if all spatial characteristics are discontinued. Thus, the categories are divided-if $5 \leq C \leq 11$, the physical characteristic maintains continuity; if $11<C \leq 21$, the physical characteristic has partly continued; if $21<C \leq 31$, the physical characteristic discontinued.

The transformations among six cases were found to be at different degrees at the levels of building structure analysis and open space analysis (Figure 13). With regard to building structure level, five spatial characteristics were found to strictly continue through morphological transformation between case 4 -case 5 . The relations between the rest of cases were partly continued. While at open space level, there was discontinuity found between case 2-case 3, and case 2-case 5, in which spatial characteristics were muted completely. In addition, spatial characteristics were continually maintained between case 4-case 5. In the understanding of continuity of spatial characteristics, this not only means the spatial characteristics physically and directly continued to another (such as spatial characteristics found in the same morphological period), but also presents in different types of forms with shared common design principles. For example, the spatial relationship 
of public $\rightarrow$ semi-private $\rightarrow$ private was found in imperial case 1 , but it was also found at cases 4,5 and 6 . Although their typologies were different, at a spatial relationship scale the physical characteristic was continued.

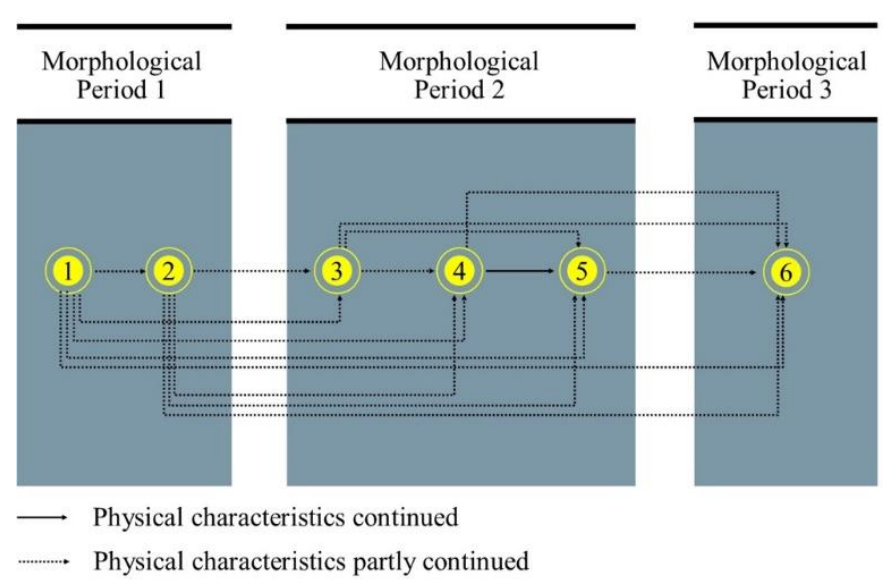

(a)

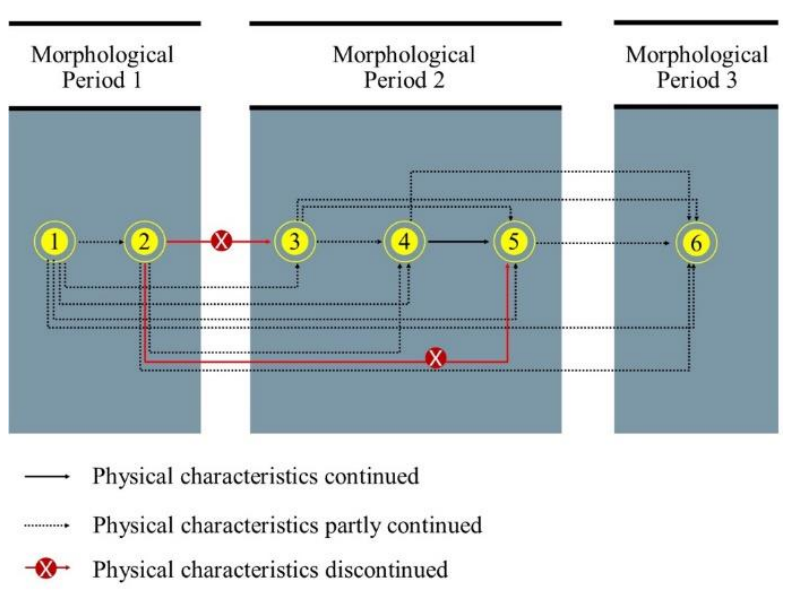

(b)

Figure 13. Overall analysis results in continuity of spatial characteristics between cases. (a) shows the spatial changes between periods at building scale; and (b) presents the spatial changes between periods at open space scale.

\section{Key Findings}

Based on the analysis above, the key findings are very clear. Through the transformation of the urban development and changes of political-socio-economic ideologies, both historically and due to current globalization influences, the layout, design and functions of buildings are transformed in each period to follow the changes and influences of these ideologies and fulfill permanent or contemporary needs. Due to transformations of political-economic-socio-cultural ideologies, the spatial structure of the neighborhood is dramatically changed through time. The political ideology is key throughout the design of the buildings and planning of the city in imperial times to emphasize socio-political priority, in which the higher social class was located in the center of the block and along the main streets, while lower social classes gradually decentralized to the edge of the block and mostly occupied secondary streets and small lanes. The same design principle of socio-political hierarchy applied in the spatial design of houses to represent the social class of each family, and thus, the spatial characteristics of the buildings were originally designed to address socio-political ideologies, and their spatial structure involved areas in the front and back (where servants and female members of the families lived) that gradually centralized to the center (where senior or male members of the family lived).

In period two, political ideology still played the key role throughout the development of the city, although the design ideas were different from imperial times. The socialist ideas and collectivism were largely applied to regeneration of historical neighborhoods, which transformed the traditional private houses into shared properties to address the core sociopolitical ideology — social equity — and the spatial layout of houses was then organically regenerated by each family who occupied the property, without regulatory control. As a consequence, the regeneration of traditional courtyard houses in the area converted from one family owned homes to multi-family occupied residences (case 1 and 2), and part of originally residential buildings are now being turned from pure residential to mixed commercial functions (case 2), in order to satisfy increased commercial activities and needs. In the meantime, in terms of its spatial structure, it first transformed internal shared space and then expanded horizontally to external public open spaces, and grew up vertically to respond continually increased population (case 1 and 2), which also caused the internal road network of the block to be transformed from open access to blind alley. On the other hand, soviet style modern buildings for laborers started to be built freely by work units 
in the neighborhood without planning and spatial control, but also to emphasize socialist ideas and the collectivist lifestyle (cases 3, 4 and 5). Due to the lack of building regulations to control the construction in historical neighborhoods, the transformation of the buildings and even the entire neighborhood was seen as a result of negotiations between neighbors.

Since post-reform, the economic ideologies of the global market have started to replace the socio-political ideologies that led the development of the neighborhood. The impact of mass global culture brought enormous socio-cultural conflict, changing urban development, and resulting in higher density international style modern buildings (case 6). Large scale individual modern architecture began in Chinese cities. Due to lack of building and planning regulation control and design, these high raised modern buildings created huge visual diversity in narrow lanes, which further limited the external spaces, and largely changed the way of living and pattern of use, both internal and external, of buildings.

In contemporary use of all cases, the interesting part is after the transformation of political-economic-socio-cultural ideologies and forms of building typologies, the spatial sequence remains the same as vernacular design, which follows the public-semi-publicprivate pattern. Even if the houses have been changed from private to shared ownership, the residents will have built up a transitional semi-private space themselves slowly through time, which remains the preferred spatial sequence (case 1).

Therefore, the spatial sequence, plot arrangement and spatial movement of most cases continually adapt to local needs, and maintain memories and meaning associated with local place. On the other hand, the other aspects only remain partly adapted to the local preferences in use, and whether they can be continued depends on transformation of political-socio-economic ideologies, and this explains the most important mutation between period 1 and 2 .

\section{Conclusions}

This study has developed an analytical framework to investigate changes of spatial characteristics in adaptation to the changing of local needs for improving socio-cultural sustainability in historical neighborhoods in the context of Beijing, China. The key contributions of the research are twofold: firstly, due to lack of studies on adaptation of local needs from a physical perspective for sustaining socio-cultural sustainability in the context of China, particularly Beijing, this paper identifies continuities and discontinuities of spatial characteristics, which are as follows:

(1) Continuities of spatial characteristics - continually supporting transformation of local needs through time and mutations of political-economic-socio-cultural ideologies. The analysis results could be used to support regulations and policies that fill the gaps of legislation in spatial design for sustaining socio-cultural sustainability.

(2) Discontinuities of spatial characteristics-discover the gaps to adapt local sociocultural needs in spatial design. On the other hand, some of them may also see new lifestyles identified in case studies, such as automobile use, and demands for in parking facilities.

Secondly, the proposed method for analyzing physical forms of cases improves clarity and consistency in defining and analyzing typological cases at an articulated scale, pairwise comparison and categorization of the three degrees of morphological changes. This analytical method is applicable to other cities and countries that improve efficiency to quickly define continuities and discontinuities of spatial characteristics for maintaining or improving, which improve socio-cultural sustainability of a neighborhood.

The limitations of the study might involve three aspects. Firstly, one may ask to what degree each spatial characteristic analytical framework contributes to local needs in terms of socio-cultural sustainability, and whether there are other factors affecting these needs that influence socio-cultural sustainability. Secondly, the analytical framework was only tested in a historical neighborhood (covers vernacular, soviet style and international style raised buildings, but high raised towers are not available in this area) in Beijing. Although the results include clear identifications of continuity, partial continuity or discontinuity 
of spatial characteristics in adaptation of local needs, it still needs more evaluations of variant types of neighborhoods in different context. Finally, the decision made for a case in regard to continuity and mutation in its spatial transformation was made based on score calculation. However, if the calculation range was set to a larger number, then partial continuity might reduce and continuity would increase.

In order to reduce limitations of the study, further research with a bigger sample size with more house types in different contexts could be explored to provide a fuller picture of how changes of spatial characteristics could improve socio-cultural sustainability by evaluating the adaptation to local needs. The degree of each spatial characteristic's contribution to the impact of spatial changes in relation to adaptation of local needs would also be interesting to study. Larger score range of calculation of continuity and discontinuity of spatial characteristics should be tested with a larger sample to justify the stability and applicability of the analytical framework.

Author Contributions: Conceptualization, H.L. and B.L.; methodology, H.L.; software, H.L.; validation, H.L. and B.L.; formal analysis, H.L.; investigation, H.L.; resources, H.L.; data curation, H.L.; writing —original draft preparation, H.L. and B.L.; writing—review and editing, H.L. and B.L.; visualization, H.L.; supervision, B.L.; project administration, B.L.; funding acquisition, B.L. All authors have read and agreed to the published version of the manuscript.

Funding: This research is supported by National Natural Science Foundation of China: 41871154.

Institutional Review Board Statement: Not applicable.

Informed Consent Statement: Not applicable.

Data Availability Statement: The data presented in this study are available on request from the corresponding author. The data are not publicly available due to privacy concerns.

Acknowledgments: Great appreciation to Lu Yi, who offers great assist in development of formulas in the study.

Conflicts of Interest: The authors declare no conflict of interest.

\section{References}

1. Krier, R.; Rowe, C. Urban Space; Academy editions London: London, UK, 1979.

2. Relph, E. Place and Placelessness; Pion: London, UK, 1976.

3. Zheng, J. Conservation Planning For Heritage Sites: A Critical Review and Case Studies; Courtauld Institute of Art (University of London): London, UK, 2007.

4. Chen, F. The design dimension of China's planning system: Urban design for development control. Int. Plan. Stud. 2016, 21, 81-100. [CrossRef]

5. Chen, F.; Ludwig, C.; Sykes, O. Heritage Conservation through Planning: A Comparison of Policies and Principles in England and China. Plan. Pract. Res. 2020, 1-24. [CrossRef]

6. Wu, L. The Old City of Beijing and its Juer Hutong Neighbourhood; China Architecture \& Building Press: Beijing, China, 1994.

7. Whitehand, J.W.R.; Gu, K.; Conzen, M.P.; Whitehand, S.M. The Typological Process and the Morphological Period: A CrossCultural Assessment. Environ. Plan. B Plan. Des. 2014, 41, 512-533. [CrossRef]

8. Zhang, D. Courtyard Housing for Health and Happiness: Architectural Multiculturalism in North America; Routledge: London, UK, 2016.

9. Butina Watson, G.; Bentley, I. Identity by Design; Routledge: London, UK, 2007.

10. Castells, M. The Power of Identity; Wiley: Chichester, UK, 2010.

11. Cody, J.; Siravo, F. Historic Cities: Issues in Urban Conservation; Getty Publications: Los Angeles, CA, USA, 2019.

12. Sepe, M. Principles for Place Identity Enhancement: A Sustainable Challenge for Changes to the Contemporary City; WIT Press: Southampton, UK, 2012.

13. Caniggia, G.; Maffei, G.L. Composizione Architettonica e Tipologia Edilizia; Marsilio Venezia: Venezia, Italy, 1979.

14. Chen, F.; Thwaites, K. Chinese Urban Design: The Typomorphological Approach; Routledge: London, UK, 2018.

15. Lynch, K. The Image of the City; MIT Press: Cambridge, MA, USA, 1960.

16. Rapoport, A. Human Aspects of Urban Form: Towards a Man-Environment Approach to Urban form and Design; Elsevier: Oxford, UK, 2016.

17. Nurse, K. Culture as the fourth pillar of sustainable development. Small States: Econ. Rev. Basic Stat. 2006, 11, 28-40.

18. Hawkes, J. The Fourth Pillar of Sustainability: Culture's Essential Role in Public Planning; Common Ground: Oxford, UK, 2001.

19. Ledent, G.; Komossa, S. Referential types as clues for housing design. Urban Morphol. 2019, 23. Available online: http: //hdl.handle.net/2078.1/211493 (accessed on 22 April 2021). 
20. Gauthier, P. Conceptualizing the social construction of urban and architectural forms through the typological process. Urban Morphol. 2005, 9, 83-93.

21. Gauthiez, B. The history of urban morphology. Urban Morphol. 2004, 8, 71-89.

22. Moudon, V. Getting to Know the Built Landscape: Typomorphology, Type and the Ordering of Space; Van Nostrand Reinhold: New York, NY, USA, 1994.

23. Gu, K.; Tian, Y.; Whitehand, J.; Whitehand, S.M. Residential building types as an evolutionary process: The Guangzhou area, China. Urban Morphol. 2008, 12, 97-115.

24. Feng, Q. A Typo-morphological Enquiry into the Evolution of Urban and Architectural Forms in the Huangpu District of Shanghai, China; Concordia University: Montréal, QC, USA, 2014.

25. Oliveira, V.; Monteiro, C.; Partanen, J. A comparative study of urban form. Urban Morphol. 2015, 19, 73-92.

26. Jive' n, G.; Larkham, P.J. Sense of place, authenticity and character: A commentary. J. Urban Des. 2003, 8, 67-81. [CrossRef]

27. Southworth, M.; Ruggeri, D. Beyond placelessness: Place identity and the global city. In Companion to Urban Design; Routledge: London, UK, 2011.

28. Healey, P. Building institutional capacity through collaborative approaches to urban planning. Environ. Plan. A 1998, 30, 1531-1546. [CrossRef]

29. Caniggia, G.; Maffei, G.L. Interpreting Basic Building: Architectural Composition and Building Typology; Alinea: Alinea, IL, USA, 2001.

30. Kropf, K. Aspects of urban form. Urban Morphol. 2009, 13, 105.

31. Kropf, K. The Handbook of Urban Morphology; John Wiley \& Sons: Chichester, UK, 2018.

32. Gokce, D.; Chen, F. A methodological framework for defining 'typological process': The transformation of the residential environment in Ankara, Turkey. J. Urban Des. 2019, 24, 469-493. [CrossRef]

33. Liu, H. Locally Responsive Public Space Design: A Spatial Reference to Beijing; Oxford Brookes University: Oxford, UK, 2020.

34. Norberg-Schulz, C. Genius Loci: Towards a Phenomenology of Architecture (1979). Hist. Cities: Issues Urban Conserv. $2019,8,31$.

35. Carmona, M.; Heath, T.; Tiesdell, S.; Oc, T. Public Places, Urban Spaces: The Dimensions of Urban Design; Routledge: London, UK, 2010.

36. Canter, D.V. The Psychology of Place; Architectural Press: London, UK, 1977.

37. Tuan, Y.-F. Space and Place: The Perspective of Experience; U of Minnesota Press: Minneapolis, MN, USA, 1977.

38. Proshansky, H.M.; Fabian, A.K.; Kaminoff, R. Place-identity: Physical world socialization of the self. J. Environ. Psychol. 1983. [CrossRef]

39. Hague, C.; Jenkins, P. Place Identity, Participation and Planning; Psychology Press: East Sussex, UK, 2005.

40. Sepe, M. Creative urban regeneration between innovation, identity and sustainability. Int. J. Sustain. Dev. 2009, 12(2), 144-159. [CrossRef]

41. Bentley, I. Urban Transformations: Power, People and Urban Design; Routledge: London, UK, 2004.

42. Castells, M. An introduction to the information age. City 1997, 2, 6-16. [CrossRef]

43. Abel, C. Architecture and Identity: Responses to Cultural and Technological Change; Routledge: London, UK, 2017.

44. Lynch, K. Good City Form; MIT Press: Cambridge, MA, USA, 1981.

45. Gainza, X. Culture-led neighbourhood transformations beyond the revitalisation/gentrification dichotomy. Urban Stud. 2017, 54, 953-970. [CrossRef]

46. Lees, L.; Phillips, M. Handbook of Gentrification Studies; Edward Elgar Publishing: Camberley, UK, 2018.

47. Zukin, S. Landscapes of Power; University of California Press: Berkeley, CA, USA, 1991.

48. Brundtland, G.H.; Khalid, M.; Agnelli, S.; Al-Athel, S.; Chidzero, B. Our Common Future; Oxford University Press: New York, NY, USA, 1987.

49. Langhelle, O. Towards Sustainable Development: On the Goals of Development-and the Conditions of Sustainability; Springer: New York, NY, USA, 1999.

50. Pearce, D.; Markandya, A.; Barbier, E. Blueprint 1: For a Green Economy; Routledge: London, UK, 2013.

51. Lim, R. Traditions as magic: Involving tradition in the creative process for contemporary architecture. J. Res. Archit. Plan. 2008, 7, $1-17$.

52. Knox, P.; Pinch, S. Urban Social Geography: An Introduction; Routledge: London, UK, 2014.

53. Crang, M. Cultural Geography; Routledge: London, UK, 2013.

54. Zetter, R.; Watson, G.B. Designing sustainable cities. In Designing Sustainable Cities in the Developing World; Routledge: London, UK, 2016; pp. 3-18.

55. Eizenberg, E.; Jabareen, Y. Social sustainability: A new conceptual framework. Sustainability 2017, 9, 68. [CrossRef]

56. Porotto, A.; Ledent, G. Crisis and Transition: Forms of Collective Housing in Brussels. Buildings 2021, 11, 162. [CrossRef]

57. Moudon, A.V. Urban morphology as an emerging interdisciplinary field. Urban Morphol. 1997, 1, 3-10.

58. Oliveira, V. Urban Morphology: An Introduction to the Study of the Physical Form of Cities; Springer: Cham, Switzerland, 2016.

59. Goodey, B. Human Space: Where You'are At; Penguin: Middlesex, UK, 1974.

60. Sklair, L. The Icon Project: Architecture, Cities, and Capitalist Globalization; Oxford University Press: Oxford, UK, 2017.

61. Corsini, M.G. Residential building types in Italy before 1930: The significance of local typological processes. Urban Morphol. 1997, 1,34-48.

62. Dufaux, F. A new world from two old ones: The evolution of Montreal's tenements, 1850-1892. Urban Morphol. 2000, 4, 9-19.

63. Maretto, M.; Scardigno, N. Muratorian urban morphology: The walled city of Ahmedabad. Urban Morphol. 2016, 20, 18-33. 
64. Gygax, F. The morphological basis of urban design: Experiments in Giudecca, Venice. Urban Morphol. $2007,11,111$.

65. Ryan, B.D. Morphological change through residential redevelopment: Detroit, 1951-2000. Urban Morphol. 2006, 10, 5.

66. Satoh, S. The morphological transformation of Japanese castle-town cities. Urban Morphol. 1997, 1, 11-18.

67. Racine, F. Developments in urban design practice in Montreal: A morphological perspective. Urban Morphol. 2016, $20,122-137$.

68. Siksna, A. The effects of block size and form in North American and Australian city centres. Urban Morphol. 1997, 1, 19-33.

69. Wu, L. Rehabilitating the Old City of Beijing: A Project in the Ju'er Hutong Neighbourhood; UBC Press: Vancouver, BC, Canada, 2011.

70. ZHAO, C.; SHEN, M.; ZHANG, J. The Soviet Union style of urban planning in China: Retrospection and implications. Urban Plan. Forum 2013, 2, 109-118.

71. Zhang, F. China's Urbanization and the World Economy; Edward Elgar: Camberley, UK, 2014.

72. Zhang, L.; Ding, W. Changing urban form in planned economy: The case of Nanjing. Urban Morphol. 2018, 22, 15-34.

73. Yi, J. Urban Management of Ancient Beijing; Tongxin Press: Beijing, China, 2002.

74. Zhu, J. Chinese Spatial Strategies: Imperial Beijing, 1420-1911; Psychology Press: East Sussex, UK, 2004.

75. Chai, Y.-w.; Chen, L.-J.; Zhang, C. Transformation of Danwei System: An Angle of View on City Changes in China. World Reg. Stud. 2007, 4, 60-69. 